\title{
MAMMALS OF AUSTRALIA.
}

ge 





\section{MAMMALS OF AUSTRALIA,}

JHHJSTRATEP BY

MISS HARRIETT SCOTT, AND MRS. HELENA FORDE,

FOR THE

Council of extration;

WITH

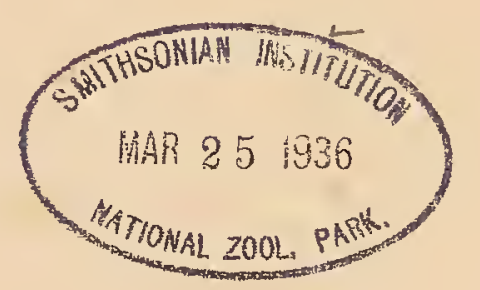

A SHORT ACCOUNT OF ALL THE SPECIES HITHERTO DESCRIBED.

BY

GERARD KREFFT, F.L.S., \&.

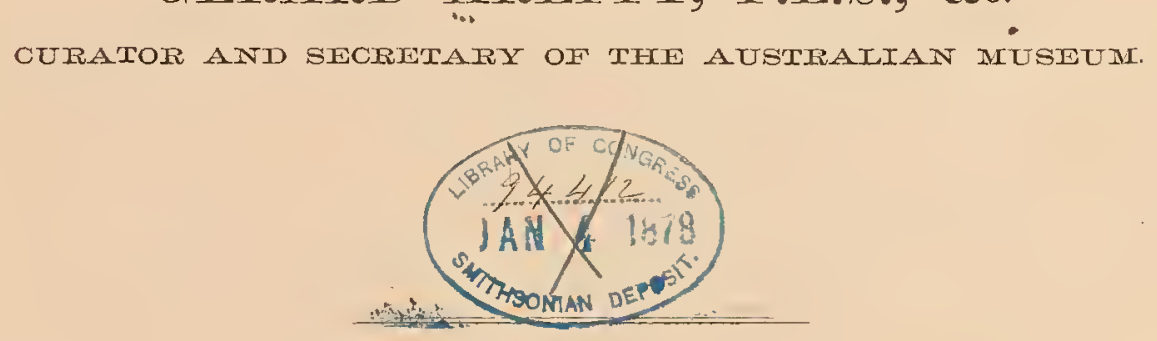

SYDNE.Y :

THOMAS RICHARDS, GOVERNMENT PRINTER.

ז 87 . 



\section{PREFACE.}

THE following plates representing some of our Mammals, for which these brief descriptions have been written, were published, in the first instance, by the Council of Education, as Object Lessons, for the use of their Schools.

Mr. A. W. Scott, M.A., was entrusted with their execution, and his talented Daughters, Miss Scott and Mrs. Ilelena Forde, lithographed them. Most of the Drawings were taken from life-photographs, and the rest from the best mounted spccimens that could be procured. Only 16 Animals are represented herein; but a general summary is given of those which are not figured. It is to be hoped that the Council of Education will continue this very useful Work to completion.

The letter-press supplies all the most neccssary information, including remarks on the anatomy and the geographical distribution of the animals referred to. The price of Mr. Gould's elaborate Work places it beyond the reach of ordinary means, and Mr. Waterhouse's "Natural History of Mammalia"- the best treatise on the Marsupiata ever published-has becn long out of print, so that the present Book may be considered the only one of its kind now available.

A general summary of our Vertcbrata will be found in that useful publication "The Industrial Progress of New South Wales"-but it is too short to be of much use to the Student, though sufficient to dispel many popular errors. Works of this kind deserve more encouragement; and it may not be out of place to mention here that a valuable series of Plates illustrative of our fossil Mammals, drawn by the same artists, together with Geological Maps of the Wcllington Cares and the surrounding country, by Professor Alexander M. Thomson, Dr., Sc., of the Sydney University, are in the hands of the Trustees of the Museum, ready for publication so soon as the necessary funds shall have bcen provided.

The Council of Education will perhaps allow me this opportunity to appeal to residents in the Country Districts for contributions to our national collection. The Echidna and the Ornithorhynchus, shot during August, Septembcr, and October, but especially their young, being the most desirable donations. Other specimens, such as Fossil Remains of all kinds, sun or smokc-dried Skeletons, Skins of Mammals, Birds, Reptiles, Fishes, and Small Animals in brine, Insects and Shells in spirits-will be thankfully rcceived and duly acknowledged by the Trustees. A most valuable gift, the young of an Echidna or Spiny Ant-eater (not larger than a French bean), was lately presented by Mr. Sydney Hill, being the second specimen of so small a size ever obtained, and yet the Echidna was discovered nearly a century ago, and described so far back as 1792. It is strange, but true, that not a single very young Ornithorhynchus, or Duck-mole, is in one of the Museums in Australia; the specimens which Dr. Bennett captured in 1834 were unfortunately lost, and I am not aware that others have been secured since. These facts show sufficiently that the study of Natural Ilistory, in which many persons feel interested, is still much neglected. No doubt everybody is desirous of finding new or curious objects, but the consequence is that the more common specimens are excecdingly $\backslash$ rare in collections, and cannot be referred to when required.

What, for example, is of greater value to the Farmer, the Brecder, or the Veterinary, than a series of skeletons of our domestic animals, showing the differences in their bony frame; or sets of skulls to illustrate the changes which the teeth undergo. Certainly there are books on these subjects, but the examination of such specimens is more instructive than many pages filled with description. Objects of this kind are easily prepared on large Stations, and would form more desirable gifts to the Museum than the malformed animals which are so frequently presented in the mistaken belicf that they are the most appreciated by the public. But there are better reasons why the teeth in particular should be well studied. The sufferings which result from disregard of natural laws should be forcibly impressed upon children; and they should frequently be reminded that the second set of teeth which they receive from a bountiful Creator is also the last.

Ready at all times to give information to visitors to the Museum, I specially invite Teachers to come, with their school-children, and inspect the Objects of Natural History and Ethnography exhibited. The collection is the most complete, as regards Australian specimens, ever brought together either here or elsewhere; the only great want now being the Catalogue, which doubtless will be provided so soon as the Trustees find the means of publishing it. 



\section{Ilammals of Australia.}

TABLE OF CONTENTS.

a. Animals without a Pouch or Stin-fold for the protection of their young, forming the Order of

\section{PLACENTALIA,}

PLATE I,-FLyivg Fox, and general account of Australian Bats. Plate II.-Dingo, or Arstratian Native Dog.

PLATE III.-Signr, and list of Seals inhabiting the Antaretie Ocean.

PLATE IV.-WATER Rats, and general list of Australian Rats and Micc.

b. Animals supplied with a Pouch or Skin-fold for the protection of their young, which are very small when born, forming the Order

\section{MARSUPIALIA.}

PLATE V.-Tasmanian Wombat, with account of other species.

PLATE VI.-NATTVE BEAR.

PLATE VII.-Ring-tail Phalayger, and account of Phalanger Family

Plate viti.--Vutping Piatantagr.

PIate IX.-Tasmanian Pefalanger.

PLATE X.-Kangaroo.

PLA'CE XI.- Kangaroo, and account of the Family; also account of the Bandicoots.

PLATE XII.-Tasmanian Tiger, and account of the Dasyurilae or Native Cat Family

PLATE XIII-N $\mathrm{N}_{\text {ATIVE }} \mathrm{C}_{\mathrm{ATS}}$. Short account of common specics.

c. Animals desitute of tecth, or when these are present formed of a horny substance. The female of one yenus (Echidna) is supplieed with two small pouches without nipples, in which the young are carvierl

\section{MONOTREMATA.}

PLATE XIV.-ANT-EATER.

PLATE XV.-Dtck-billed Platypus. 



\section{INTRODUCTION.}

The Fauna of Australia is as peculiar as its Flora; and comparing the Mammals with the inhabitants of other Countries, the observer is struck by the total absence of the grcat groups of Ruminants, Pachyderms, and Plaeental Carnivores, with whieh the plains and forests of Europe, Africa, and America abound. Australia is pre-eminently the land of the Marsupials, or Pouched Animals, the more highly organized Placentals being feebly represented by a species of Dog, a few Seals, many species of Bats, and numcrous Rodents or Rats. Reviewing these families, we cannot but notice that two groups, namely, the Seals and Bats, have peculiar advantages in their mode of loeomotion, and may have reached the Great South Country with little difficulty. The Dog has always been considered to be introduced by Man, and if so, our raee must have visited Australia at an early age, though it is more likely that the Dog, the Rats, and the Pouched Animals cxisted togetller long before Man made his appearance in this part of the World.

There ean be no doubt that the Australian Continent was much larger at one time, and that the numerous islands seattered over the Banda and Arafura Sea, such as Aru, Coram, New Guinea, and, farthcr cast, the Solomon's and New Hebrides Islands, formed, with New Holland proper, a more or less compact mass, in which the Marsupial Fauna was predominant.

The smaller islands are either destitute of Mammals (exeept Bats), or, if they posscss any, they belong to the pouched tribe. From New Guinea, a Pig (Sus papuensis) has been recorded, also a small Placental Insectivore (Paradoxurus hermaphrodita); the Marsupials amount, however, to eight genera and ten species. Besides, the interior of New Guinea, with its high tableland, and snowy pealss of over 13,000 feet in height, is still a sealed book to the geographer and the naturalist; though, with all our scant knowledge, some of the most peculiar forms of marsupial life, the Trec-kangaroos, have been discovered in its sombre forests. Who can say how many more of the Creator's wondrous animals may yet be found when this the largest island of the Globe is brought under the influence of civilization. There are several Marsupials whieh New Guinea, the Aru Islands, and Northerm Australia have in common, so that the supposition of these islands being at one time joined to the Australian Continent is more than probable.

Before we consider the recent Fauna of Australia, it is necessary to go back to the evidence of fossil remains whieh many caves and alluvial deposits have yiclded up. These remains prove clcarly that the Country was inhabited in former ages by animals often larger than, but always similar in structure to, our present Kangaroos or Phalangers. The first group, the grass-eating Kangaroos, Wallabics, Kangaroo-rats, Phalangers, and Wombats, abounded; there is evidence cren of the Koala, or Native Bear, and of a small Flying Phalanger not larger than a Sugar Squirrel (Belideus); but there is also clear proof of gigantic creaturcs roving over our plains, or perhaps inliabiting the ancient swamps and rivers, which in size can only be compared to the Rhinoceros or the Hippopotamus. The teeth of thesc large species, in their form, number, and distribution, resemble, with some modification, those of the Phalangers; and the ustral formula, which holds good in reeent species, varies but slightly in the large fossil ones. When we examine the dentition of a Diprotodon, the largest of the tribe, we find six incisors above and two below (that is, three and one respectively in each ramus). We also notice one premolar and four molars or grinders in each ramus, above and below. The tusks, or first pair of upper, and the two incisive lower teeth, are coarse, not very regular, and evidently designed for the cutting of thiek, rank herbage, 
such as reeds or twigs, on which these animals probably browsed. When by a changc of climate, or from other causcs, the bogs, with their rich vegetation, disappeared, the great Diprotodons must have found it hard to make a living, and naturally succumbed to the altered circumstances, and became extinct. The smaller Kangaroos, with their admirable dentition and scissor-like lower jaws, nipped the grass if it was ever so scanty; and many of these ancient species having successfully fought for existcnce,.still live on. There must have been many more Herbivorous Marsupials than at present, because many of the remains discovered differ much from recent bones and teeth. Sometimes portions of skeletons are noticed, however, which clearly indicatc animals of the Kangaroo and Phalanger tribe, identical with living ones; but all the gigantic species have ccased to exist. We gather from the fossil remains that the bulkier kimds stood low on their legs, and that they progressed in the same way as the Wombat; in fact, the skeleton of a Diprotodon must have resembled that of a Wombat or "Native Bear" in many points.

The extinct Kangaroo tribe is principally distinguished by having shorter and stronger tarsi than the living Kangaroos, and their mode of progress must have bcen therefore slower.

Another gigantic animal, the Zygomaturus, first described by the late Mr. W. S. Macleay, M.A., belongs to the same group as the Diprotodon; its incisor teeth are however more feeble, and bear a still closer resemblance to those of the Phalangers. Numerous lower jaws in our collections indicate at least fifteen or more large species of either Diprotodon or Nototherium, so that we cannot enumerate less than twcnty gigantic grass-eating Marsupials bclonging to our extinct Fauna. If we add to these at least fifty species of Kangaroos, Wallabies, and Kangaroo Rats, and twenty species of Wombats, with a few Phalangers, we bring the Herbivorous Marsupials of Postpleiocene Australia in round numbers to cighty-five species. It is generally considered in conformity with the laws - of the Creator, that the undue increase of prolific animals should be checked by beasts of prey, and this duty appears to have been assigned to a few small but very ferocious species, the remains of which occur in large quantities at the Wellington Caves. These Carnivores comprise the Thylacinus and Sarcophilus, probably two species of each, which are now completely extinct on the Australian mainland but still exist in Tasmania. Besides these large Dasyures, several small ones, from the size of a "Tiger Cat" (D. maculatus) to that of a small Mouse (Antechinus) inhabited the country then as they do now. To these species we must add a Dog, fossil remains of which have been found in limestone cares, but no formidable Carnivore equal in power to a Lion or Tiger has yet becn discovered.

The Thylacoleo carnifex, a Marsupial with vcry peculiar dentition, and about as large as a common Bear, was evidently a true Phalanger, and of course proportionately carnivorous; it certainly was not the predacious Carnivore which checkcd the undue increase of the Diprotodons.

The last group of Marsupials, which in dentition resembles the Dasyures, and in the formation of its hind feet, the Kangaroos, has also been found in a fossil statc-we allude to the Bandicoots. A few fragmcnts of leg bones point even to the presence of an Echidna or Ant-eater of the Order IMonotremata, as yet peculiar to Australia, whilst other not determined specimens may throw additional light on the extinct Fauna of this wonderful Country, which continues to startle the World with important discoveries. It will be as well to recapitulate our extinct Fauna before noticing the recent one in detail.

ORDER PLACENTATIA.

FAuILY Canider (Dog tribe).

Remains of a Dog have been found at Wellington, but not many specimens were obtained. 
Fanilu Rodentta (Rul tribe).

From six to ten species of fossil rodents have been discovered, all of which differ much in their dentitions from other Rats, but resemble some living Australian species.

\section{ORDER MARSUPIALTA.}

Family Phascolomytdes (Tombat tribe).

Twenty fossil species, including the four still living ones.

Famili Phatangistida (Phalanger tribe).

Phalangers, Native Bears, Flying Squirrels, \&c., from fifteen to twenty gigantic species, including the genera Diprotodon, Nototherium,** Zygomaturus, and Thylucoleo; all of which are classed with the Phalangers, which they resembled in the structure of their limbs and in the position and function of their teeth.

Family Macropodm (Kangaroo tribe).

Together about fifty fossil spccies, some of which are still living.

All the gigantic Kangaroos, with short and stout tarsal bones, are now extinct.

Faviuy Perameume (Bandicoot tribe).

About five or six fossil species, which cannot be distinguished from living ones.

Familu Dasyuride (Native Cat tribe).

Four large and as many small species, the latter identical with living ones. Two large Dasyures, the Thylacinus and Sarcophilus, still exist in Tasmania, but are extinct on the mainland.

Section Monotremata (Ant-eater and Duck-bill tribe).

One or two species of the Eclidna probably existed; remains of the Platypus have not yet been found.

\footnotetext{
* The two genera Natotherizm and Zygomalurus which Professor Owen considers to be identical, differ principally in the form of their molar teeth. The first genus is founder upon nothing but lower jaws, the grinders of which resemble in their horizontal section, at the base of the crown, a loop or the figure $\infty$, but less contracted in the middle; the last grinder is always the largest. The genus $Z$ ygomaturnus, founded on a perfect skull, possesses teeth a section of which at their base would form a square, the last but one being the largest tooth of the series. I have classed all the large genera (Diprotodon, Nototherium, and Zygromalurus) with the Phalangers, because like these their teeth are inserted by tapering fangs. The Kangaroos and Wallabies have molar teeth-the fangs of which enlarge at the end, and, in aged animals, grow into the substance of the jaw, so that their removal is impossible without breaking the bone. The Wombats, again, possess teeth without roots, differing in their shape from both the Phalangers and the Kangaroos, and closely resembling the teeth of certain rodents.
} 




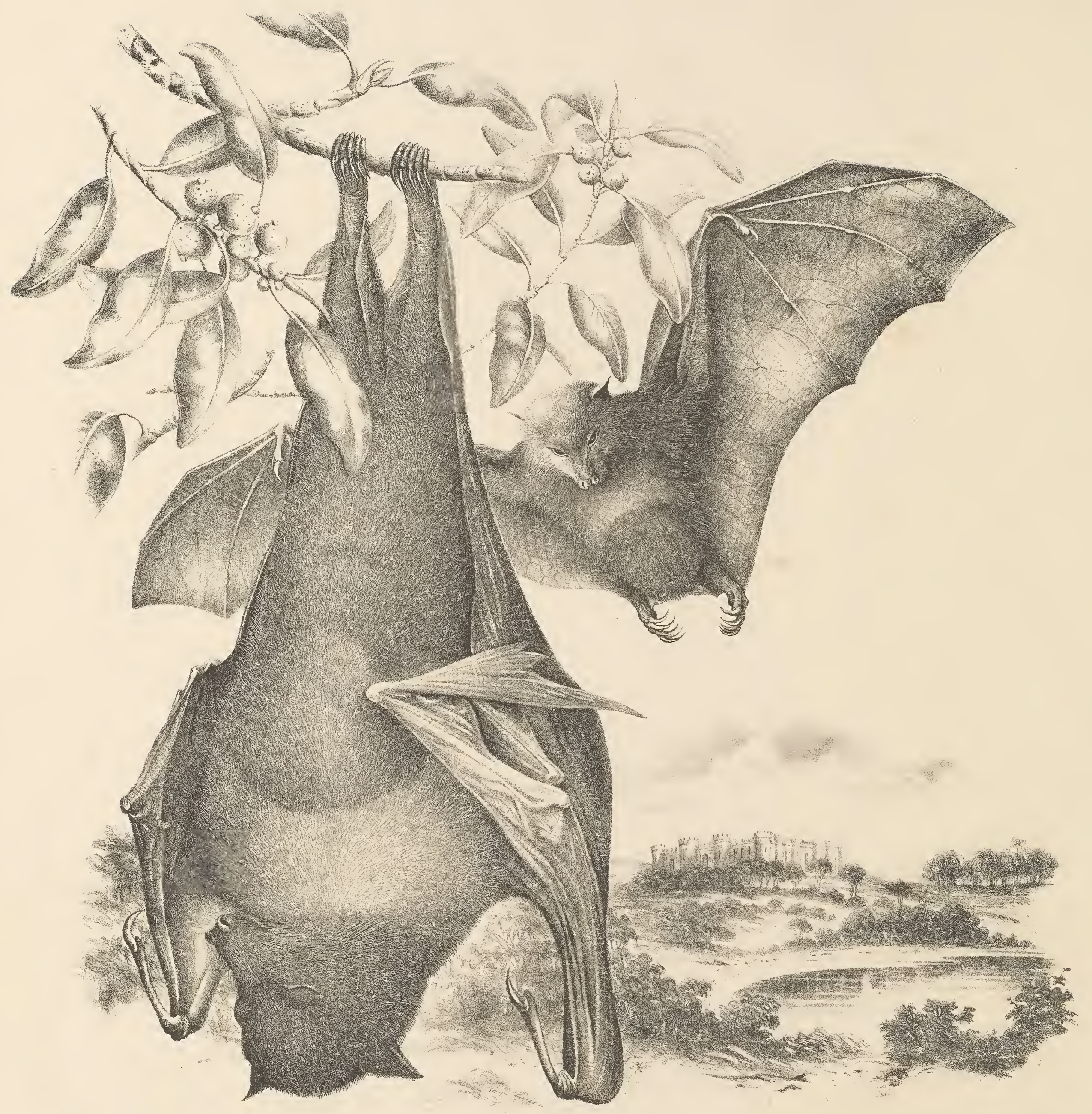

THE FLYING FOX.

(Pteropus Poliocephalus.) 


\title{
The Flying Fox.
}

\author{
(PTÉROPUS POLIOCÉPHALUS.)
}

Twentr-FIve species of Bats are known to inhabit Australia, five of which are Fruit Bats, or "Flying Foxes." The last-mentioned animals have not yet been found in any other part, except on the east coast, where they range from Cape Howe to Cape York. The figure represents the most common one-the grey-headed Fruit Bat, or "Flying Fox," which is peculiar to the New South Wales coast districts.

The food on which the "Foxes" principally rely, when garden fruit is not in season, consists of honey-bearing blossoms, and the small native figs, abounding in the coast-range scrubs. They pass the day suspended from the branches of gigantic fig-trees, as shown in our figure, and in this position they feed. The number of these creatures is almost incredible: they swing in clusters and festoons, like swarms of bees, holding on one to the other, and the weight of their bodies frequently brings down great limbs, killing many, but not appreciably diminishing them. Thousands may be noticed, at dusk, silently winging their way to some orchard, which they invade in spite of the farmers' grins, and destroy more fruit than they eat. The ground is strewn in the morning with bushels of half-devoured fruit, because they are rather dainty, and drop every pear or peach they have tasted, if it is not sufficiently sweet. The "Foxes" appear only during certain seasons in the cultivated districts, and after a few weeks" sojourn retire to the mountain forests. During this period they select a regular camping-ground, where the day is spent; and when such a place is discovered, a general battue takes place and they are killed in large numbers. These Bats are found on the east coast only, but during very dry seasons they occur as far west as the neighbourhood of Melbourne. The vegetation on the plains of the interior does not appear to suit then, as they are seldom seen west of the coast range.

The general colour is a glossy, grizzly black, with the exception of a broad rusty-red collar, covering the back of the head, neck, breast, and shoulders; the face is light grey; the ears and wing-membrane are black.

The skull is thin, almost transparent, and very light, as in all animals formed for flight; it is provided with very powerful canine teeth, which are grooved, and differ in this respect from the smooth canines of real carnivorous animals. It is highly probable that the Flying Fox is able to subsist on insects as well as on fruit. Too little, however, is known of the economy of these animals to prove this; they are observed only when fruit is plentiful, and how they subsist in the dense mountain forests can only be conjectured. The fruit of the fig-trees, and some sweet blossoms, must form their principal food at that time. The dentition consists of incisors $\frac{2-2}{2-2^{2}}$, canines $\frac{\mathrm{r}-\mathrm{r}}{1-\mathrm{x}^{3}}$ premolars $\frac{2.2}{22^{3}}$ molars $\frac{3-3}{4-4}$ $=34$ teeth. The number of young seldom exceeds one at a birth.

The name of Vampire Bat has been given to this fruit-eating animal, and many dismal tales of its blood-sucking propensities have been rife among the ignorant, but there is of course not a grain of truth in these statements. The largest species occurs in the island of Java, where it is known by the name of "Kalong," and is much esteemed as an article of food. The flesh of our "Flying Foxes" has been represented to be palatable food; it is necessary, however, to steep the males for some hours in vinegar, to take away any unpleasant smell. The following table will show the number of Bats and their habitat in Australia:-

\section{FAMILY OF BATS.}

Cheiróptera.

(a.) Truit-eating Bats, Kalongs or "Flying Foxes":-

Common Flying Fox. Pteropus poliocephalus. Brushes of New South Wales.

Spectacled Kalong. Pieropus conspicillatus. North Australia.

Funeral Kalong. Pteropus funereus. North Australia.

Cape York Kalong. Pteropus scapulatus. Cape York.

Dwarf Kalong. Petalia. (!) North-east Coast. (Not larger than a common Bat.) 
(b.) Insectivorous Bats:-

Australian Molussus. Molossus australis. Victoria.

Wilcox's Molussus. Molossus wilcoxii. East coast of Australia. Australian Taphozous. Taphozous australis. Northern Australia.

Great-eared horse-shoe Bat. Rhinolophus megaphyllus.

Fawn-coloured horse-shoe Bat. Rhinolophus cervinus. Cape York.

Orange horse-shoe Bat. Rhinolophus aurantius. Coburg Peninsula.

Geoffroy's long-eared Bat. Nyctophilus geoffroyi. West Australia.

Gould's long-eared Bat. Nyctophilus gouldi. New South Wales.

Tasmanian long-eared Bat. Nyctophilus unicolor. Tasmania.

Timor long-eared Bat. Nyctophilus timoriensis. West Australia.

Australian long-eared Bat. Nyctophilus australis. New South Wales.

Gould's short-eared Bat. Scotophilus gouldi. Southern Australia.

Chocolate-coloured short-eared Bat. Scotophilus morio. Southern and Western Australia.

Small-toothed short-eared Bat. Scotophilus microdon. Australia.

Pied short-eared Bat. Scotophilus picatus. South Australia.

Queensland short-eared Bat. Scotophilus nigrogriseus. Queensland.

Grey's short-eared Bat. Scotophilus greyi. Port Essington.

Small short-eared Bat. Scotophilus pumilus. New South Wales.

Great-footed Bat. Vespertilio macropus. South Australia.

Tasmanian Bat. Vespertilio tasmaniensis. Tasmania. 



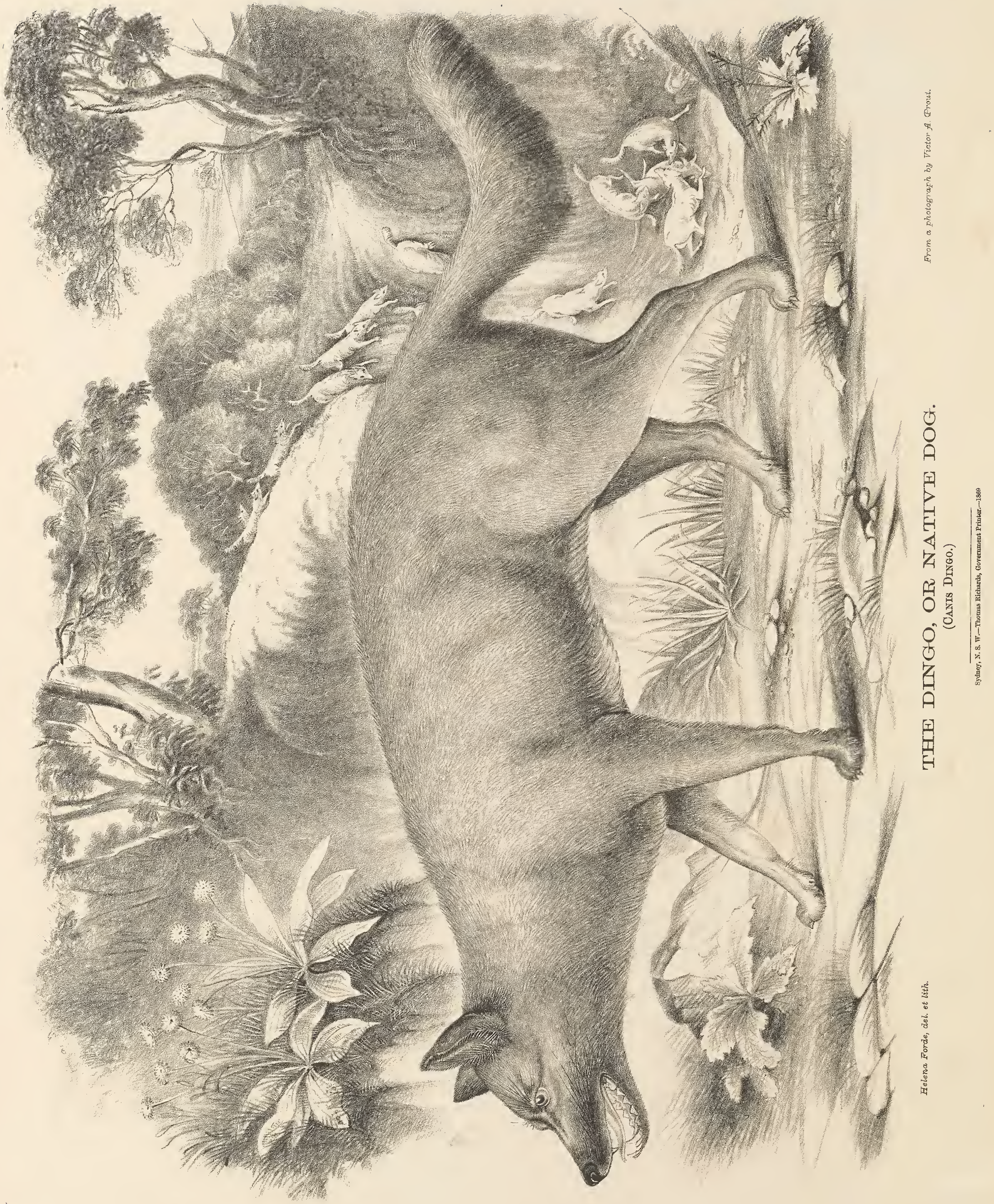




\title{
The Dingo, or Native Dog.
}

\author{
(CANIS DINGO.)
}

THERE has been much discussion among naturalists with regard to the Australian Native Dog, as to whether the animal is indigenous, or has been introduced into the Country. This is certain, however, that a species of dog existed in Australia many ages ago. Fossil remains of dogs have been discovered at the Wellington Caves, and in other localities, and it must therefore be accepted as a fact that the Dingo is indigenous.

The subject of the illustration represents the light-yellow or tan-coloured variety; colour is, however, of little importance, as the real wild Dingo is subject to as much variation as any other kind of dog. The most common shades are sandy, or tan, with whitish belly, and the inner portions of the legs and feet white; black and tan varieties are rarer.

In one of the oldest publications on Australia, "Collins' Voyage," the author, speaking of the Dingo, says,-"The dogs of this Country are of the jackall species; they never bark; are of two colours, the one red, with some white about it, the other black; some of them are very handsome." Mr. Gilbert, writing from Swan River, states,-"The Dingo is very common over all parts of this Colony. There are a very great number of varieties, marked from reddish brown to black, white, light brown, and black and white." The general belief is that a thorough-bred native $\operatorname{dog}$ is of two colours only, that it is rarely spotted, and never barks. Several real Dingos have, however, been seen with white and yellow fur, and one, which only howled before, began to bark after being chained up near an excellent watch-dog for a short time; the voice of the Dingo is short and snappish, and can be distinguished at once from that of a well-brecl domestic dog. Much has been said and written about the Dingo's cunning, his tenacity of life, and dangerous bite; it is stated that he frequently feigns death, and that he has recovered and escaped after being beaten to such an extent that one would imagine every bone in his body had been broken. A single Dingo will cause great damage to a flock of sheep, and experience proves that the wounds inflicted by its bite are generally fatal. In a case where a number of goats-ten or fifteen-had invaded a garden a tame Dingo was despatched to drive them away; but he ran from one to the other, snapping and biting right and left, and every goat bitten by him died within a few days.

The Dingo is remarkable for power, agility, and grace. A tame one which was being hunted reached his kennel long before the hounds, fairly outrunning the whole pack; and during the chase was seen frequently to clear a three-rail fence at a bound; even with a heavy chain he could jump six feet off the ground. He was rery suspicious with regard to his food, and would sooner starve than touch a piece of meat hung up on a string, neither would he take it if it had the least unusual smell. The aborigines of Australia use the Dingo for hunting purposes, and thoroughly tame it; it is no wonder, however, that they succeed in this, as they think as much of their dogs as they do of their children, and treat them as well. A "lubra" will not hesitate to rear a Dingo pup with her own offspring. A gentleman who succeeded in taming sereral Dingos, found that in one case only would the dog follow at the call of his master. The experiment of taming the Dingo is, however, always hazardous, as the acknowledged master only is respected, and everybody else snapped at furiously. The Dingo howls before rain sets in, dislikes music, and cannot bear the sound of bells; he exhibits, in fact, many traits of the domestic dog, with which he freely breeds. The aboriginal name of the Australian dog is "Warrigal" in most parts of New South Wales, and "Dwer-da" in Western Australia.

The dental formula is as follows:- Incisors $\frac{3-3}{3-3}$, canines $\frac{x-1}{1-1}$, premolars $\frac{3-3}{4-4}$, molars $\frac{3-3}{3-3}=42$ teeth. 




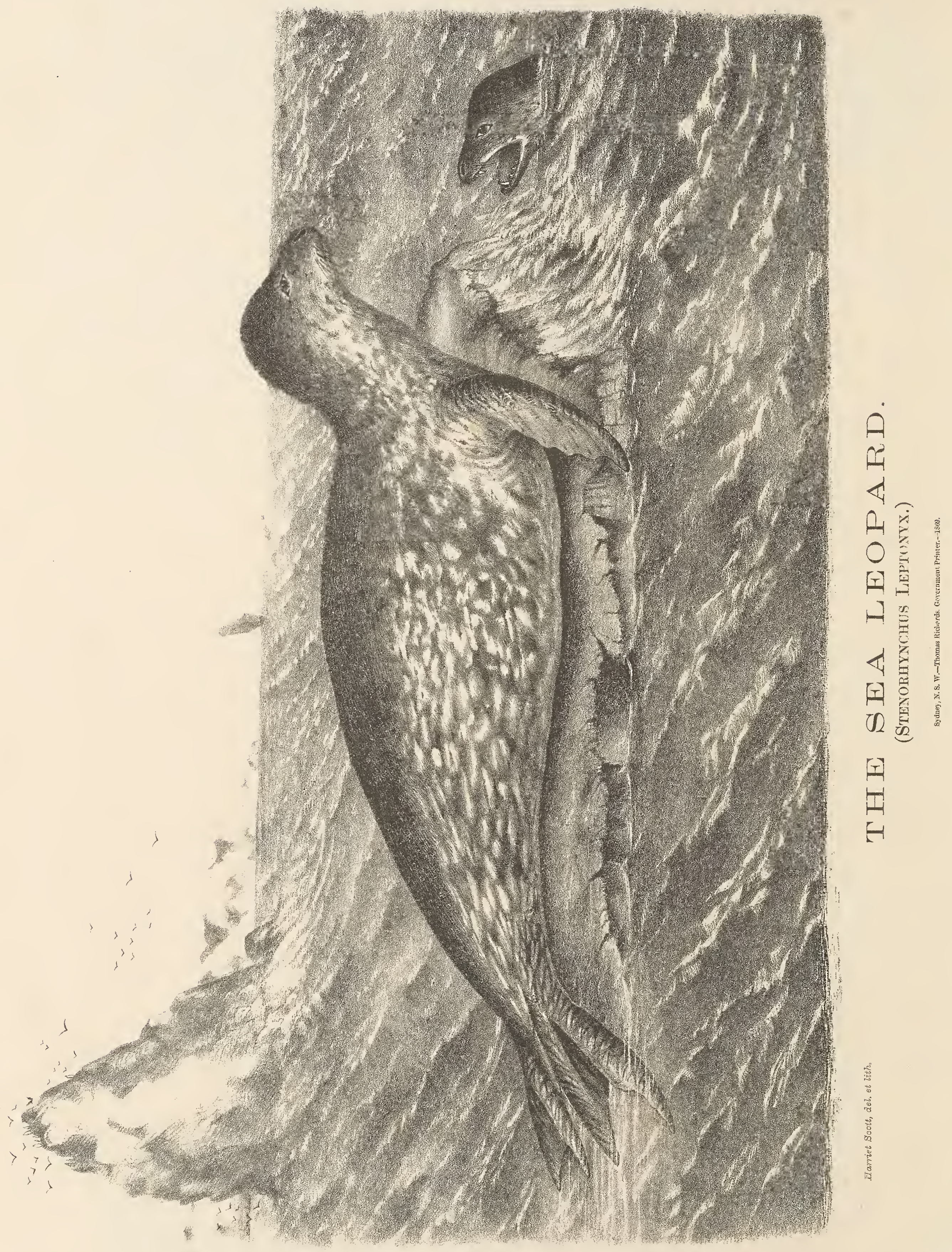




\title{
The Sea Leopard.
}

\author{
(STENORHÝNCHUS LÉPTONYX.)
}

Comparatively few Seals inhabit the Southern Ocean, and only two species occur on the Coast of New South Wales. The figure represents the largest kind, the well-known Sea Leopard, so named on account of its spotted fur, the general colour of which is a silvery grey washed with yellow; the markings are irregular, sometimes lighter than the ground colour, with a darker border, and a few uniform black spots interspersed. Young specimens and females occur without them.

This Seal grows to a considerable size, and one specimen in the Australian Museum measured fully to feet in length; it was taken at Shoalhaven, in the Illawarra District, and the stomach contained a full-grown Platypus, -a proof that the animal must have gone far up the River into fresh water. A second (female) specimen, 7 feet in length, was obtained in October, 1870 , at Double Bay, near Sydney, and kept alive for several days in the Museum grounds, where it fed on grass, no other food being at hand. It is not certain that a fish diet is absolutely necessary for the subsistence of this animal, and it is to be regretted that no experiments were made to settle this point. Dr. J. E. Gray, F.R.S., states, in one of his numerous papers on the Seal tribe, that the stomach of one contained the remains of fishes, a quantity of sea-weed, and some feathers of gulls. Our specimen would probably have subsisted on butcher's meat or fowls; but unfortunately before the trial could be made, the taxidermist had killed the creature. This Seal moved rather quickly, not unlike a snake, and turned to the right or left in an instant when in fear of attack. Water was thrown over her, but she appeared to dislike it, and lay shivering till quite dry again. The same species occurs on the coast of Tasmania. The mother produces a single young, which she protects with fin or flapper, and defends against the numerous enemies which are always in pursuit of such young creatures. It is stated that the female will not leave the spot whence her young has been taken, and grows furious in vainly attempting to sare its life.

The occasional appearance of Seals in rivers or in lagoons, where they may have remained after a flood, has probably given rise to the fable of the "Bunyip." On one occasion a so-called Bunyip's skull was presented to the Australian Museum, but proved to be that of a malformed foal. At another time some terrified IMurray natives pointed out their dreaded enemy on the other side of the river. There was certainly a large animal in the water, making a curious noise, but the night being dark it could not be seen. After a vain attempt to induce the natives to come across in their canoe, a shot was fired, the noise ceased, and a venerable he-goat was tracked the next morning to the scrub, where he had died of his wound.

It is to be deplored that such really beautiful and intelligent animals as Seals should have been destroyed so indiscriminately as they have been on this Coast. Collins, in his "Voyage to New South Wales," published in I798, mentions that the rocks in Bass' Straits and other localities were covered with Fur Seals of great beauty, but at the present time they are rarely met with in these localities. The total number of species which visit the east and south coast does not exceed three or four. The following is a list of the Seals on record as taken in the Antarctic Ocean :-

I. The crab-eating Seal. Lobodon carcinophaga. On the packed ice, South Antarctic.

2. False Sea Leopard. Leptonyx weddellii. Antarctic Ocean. South Orkney.

3. Ross's large-eared Seal. Ommatophoca rossi. Antarctic Ocean.

4. Sea Leopard. Stenorhynchus leptonyx. Coast of New South Wales, Antarctic Ocean, and Port Nicholson, New Zealand.

5. Sea Elephant. Morunga elephantina. Antarctic Ocean.

6. Hooker's Seal. Arctocephalus hookeri. Antarctic Occan.

7. Cowled Seal. Arctocephalus lobatus. North-west coast of Australia. (Hautman's Abrolhos.)

8. Falkland Seal. Arctocephalus falhlandicus. Antarctic Ocean.

9. Grey Seal. Arctocephalus cinereus. South Coast of Australia, Kangaroo Island, Western Port.

The teeth of the Seals are generally hollow, more or less lobed (except the incisors and canines), and number 6 cutting teeth above and 4 below, 4 canines, I in each ramus, and from 20 to 24 grinders. The incisors or cutting teeth vary considerably in number. 




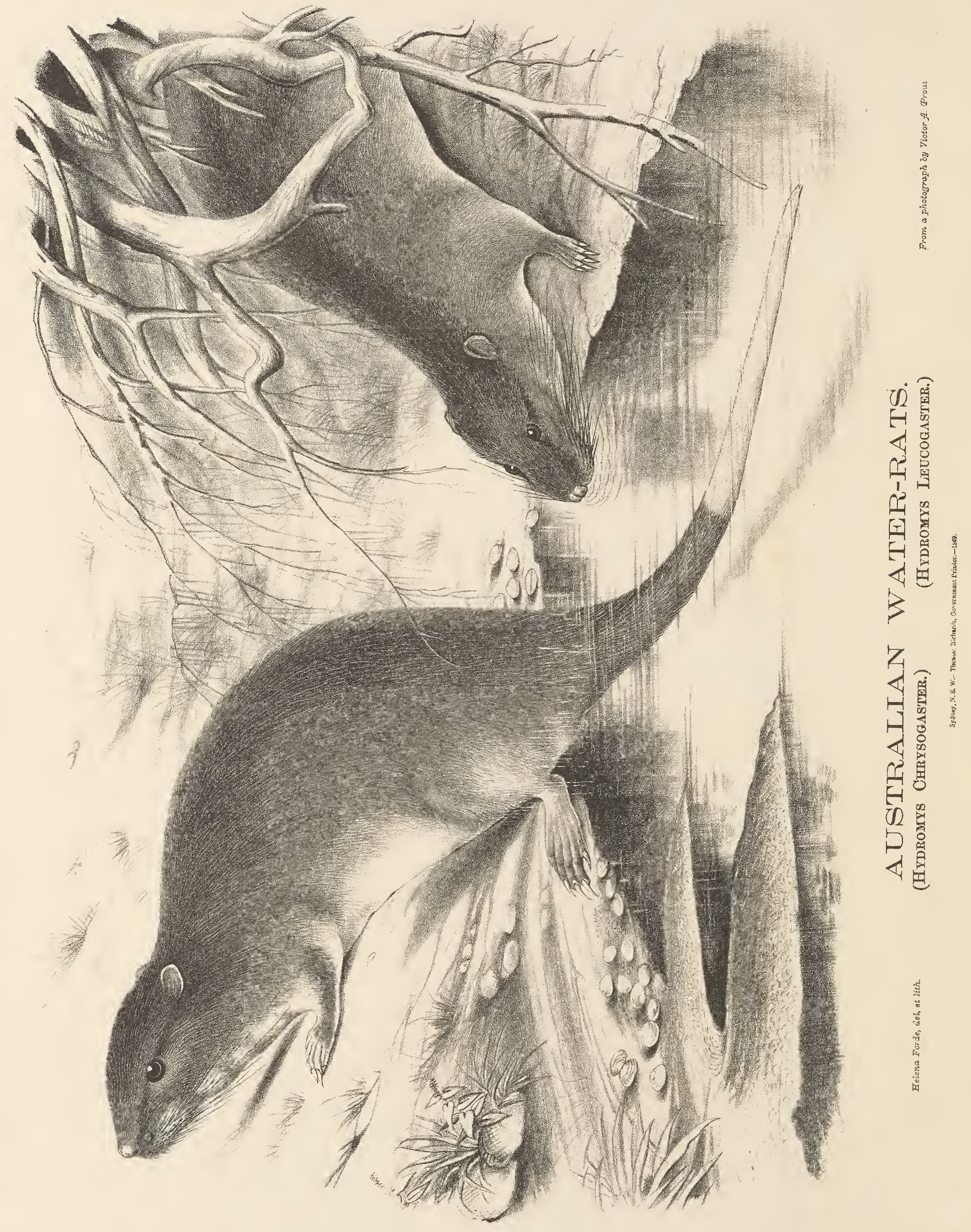




\title{
Golden-bellied and White-bellied Beaver Rat.
}

\author{
(HYDROMYS CHRYSOGASTER AND HYDROMYS LEUCOGASTER.)
}

IT is a strange fact that Beaver Rats have not yet been found beyond the Australian region, though they appear well adapted to lead an aquatic life, and seem able to cross the narrow straits dividing the mainland from New Guinea and the rarious groups of islands not strictly Australian. Whatever may be the cause, however, they do not inhabit other parts of the World, and are as peculiar to our Country as the Kangaroo.

These rats have their grinders reduced to a pair in each ramus, above and below, and differ therefore from all other Rodents. It is difficult to determine how many species there are, and we believe that the four or five which naturalists choose to class as distinct, on account of a difference in fur, are in reality mere varieties of one kind.

We have selected two well-marked species for representation,--the one bright orange, the other dirty white, beneath; the upper parts are much alike, and of a grizzly brown or black colour. The tip of the tail is white in all species but one-Macleay's Bearer Rat (Hydromys lutrilla).

Two kinds are considered particularly doubtful, namely, the Fulvous Beaver Rat (Hydromys fultolaratus), from the Murray River, and the Sooty Beaver Rat (Hydromys fuliginosus), from West Australia. The western animal is known to the aborigines of Perth as Ngoör-joo, whilst those who inhabit the country near King George's Sound call it Ngow"-ir-ri-gin. A third species was discovered by the late Mr. W. S. Macleay, in front of his residence at Elizabeth. Bay. This last rat has a uniformly dark tail, and is smaller than the others; but it is probably only an immature Hydromys leucogaster. The original specimen in the Australian Museum has lost much of the fur, and its characteristics cannot be described with that certainty which is desirable when new species are under discussion.

Beaver Rats are found in almost every part of Australia where there is permanent water; they become rare towards the tropics, and occur in large numbers in the southern streams and lagoons: are shy and nocturual in their habits; dive well, but are soon drowned when unable to find a resting-place in the water. We have frequently tried the experiment in a large tank, and found them succumb in less than an hour. This fact may throw some light on the limited distribution of the genus. Their food consists of crustaceans, fish, and water insects, but principally of a small bivalve of the genus Cyclas, which our talented artist, Mrs. Forde, informs us is to be found in the rivers of the interior in such large quantities that refuse-heaps of the empty shells always line the banks. The number of young is four at a litter, and the mother provides a burrow in the river-bank for them. The young ones are often feasted upon by snakes, and in one instance a dozen of them were taken fron the stomach of a single reptile

The bone carerns of this Country, which have been most carefully examined, did not yield remains of these curious animals, though they have afforded proof that the Terrestrial and Arboreal Rodents lived in large numbers at a former age. It is not possible to add descriptions in this paper of the numerous rats and mice that inhabit Australia; but we furnish a list of all the supposed species, which may be found interesting. When more consideration is devoted by describing authors to teeth and structure of skeleton, and less to colour and texture of fur, these numerous species will suffer a heary reduction, because one half of them are, no doubt, immature specimens, or local varieties.

The dentition of the genus Hydromys is as follows:-Incisors $\frac{2}{2}$, molars $\frac{z-2}{2-2}=12$ reeth. All other Australian rats and mice have-Incisors $\frac{2}{2}$, molars $\frac{3-3}{3-3},=16$ teeth.

'The Rodents, Gnawers, or Rats, of Australia are conveniently divided into three groups, which we name-Ist, the genus Hydromys, comprising the water rats just enumerated; 2nd, the genus ILapalotix, or the slender-eared and long-tailed rats; and, 3 rd, the genus Mus, comprising the ordinary rats and mice.

\section{Genus Hapalotis.}

(a.) Tree Rats, representing the Squirrels in Australia; tail long, and generally pencilled at the tip :1. White-footed Tree Rat. Hupalotis albipes. New South Wales. 2. White-tipped Tree Rat. Hapalotis apicalis. New South Wales. 3. Black-tipped Tree Rat. Hapalotis penicillata. North Australia. 
4. Elsey's Hapalotis, or Tree Rat. Hapalotis hemileucura. North Australia.

5. Great Hapalotis, or Tree Rat. Hapalotis hirsutus. North Australia.

6. Spotted-tailed Tree Rat.* Hapalotis (or Mus) macropus. North Australia.

7. Building Hapalotis. Hapalotis conditor. This curious rat was first discovered by the late Captain Sturt, on the Murray and Darling, and the gallant explorer gives the following description of it:- "The Building Rat inhabits the brushes of the Darling, but was not found beyond latitude $30^{\circ}$. It builds a nest of small sticks, varying in length from three to eight inches, and in thickness from that of a quill to that of the thumb, arranged in a most systematic manner, so as to form a compact cone, like a bee-hive, about four feet in diameter and three feet high. Those at the foundation are so disposed as to form a compact flooring, and the entire fabric is so firm as almost to defy destruction, except by fire. The animal, which is like an ordinary rat, only that it has longer ears, and the hind-feet are disproportioned to the fore-feet, lives in communities, and traverses the mounci by means of passages leading into the apartments in the centre. One of these nests or mounds had five holes or entrances at the base, nearly equidistant from each other, with passages leading from them to a hole in the ground beneath, in which I am led to conclude they had their store. 'There were two nests of grass in the centre, with passages running up to them diagonally from the bottom; the nests were close together, but in separate compartments, with passages communicating from the one to the other." Many years have passed since the gallant Captain explored these regions. Then only fleet-footed Wallabies disturbed the Building Rat; now herds of cattle tramp heavily over the country, and the little architect has been obliged to quit his dwelling, which is however often reoccupied by another rat-the White-tipped Hapalotis. We have had an opportunity of examining many of the curious structures described abore; but out of at least fifty, only one contained a solitary "KöHL,"-the aboriginal name for the Building Rat. The nests so examined were not empty, but, as already stated, they frequently harboured a family of the White-tipped Hapalotis, a smaller and rery gentle species-so gentle indeed as to be encouraged to share our frugal meals when we have been encamped for a few months near their habitations.

The Building Rat has large slender ears, and not a pencilled tail; it may belong to another section, but it is enumerated here for want of a better place at present.

(b.) Jerboa-like Rats. Two distinct species of jumping mice inhabit Australia; the larger is found on the West Coast, and the smaller on the Murray and Darling. These mice or rats progress on their hind legs, like the Kangaroo. They form burrows in the sandhills, which the aborigines soon find out and trace to the very end, for the purpose of obtaining the irhabitants to roast them, when they cannot procure larger game :-

8. Long-tailed Jerboa. Hapalotis longicaudata. "Kor-tung" and "Gool-a-wa" of the aborigines of Moore's River, Western Australia.

9. Mitchell's Jerboa. Hapalotis mitchellii. "Kahlpèré" of the Murray natives; "Djir-dow-in" of the aborigines near Perth; "Mat-tee-getch" of the Moore's River tribes.

\section{Genus Mus.}

The common rats of Australia, that is, species with moderate ears and tails, are numerous, and difficult to classify. We enumerate them as follows:-

Dusky-footed Rat. (Mus fuscipes.) Western Australia, South Australia, Islands of Bass's Straits, New South Wales, and probably Tasmania.

Tawny Rat. (Mus vellorosus.) A long-haired species, from South Australia. Only one specimen in existence.

Long-haired Rat. (Mus longipilis.) Probably identical with the above. A single specimen in the Australian Museum, from the Victoria River.

Buff-footed Rat. (Mus cervinipes.) A Queensland and New South Wales species, named "Corrill" by the aborigines of Stradbrook Island, Moreton Bay, and "Cunduov" by the Richmond River natives.

Allied Rat. (Mus assimilis.) "Moor-deet" of the King George's Sound tribes.

White-footed Rat. (Mus manicatus.) An allied species, from Port Essington.

Sordid Rat. (Mus sordidus.) "Dil-pea" of the aborigines of the Darling Downs District, New South Wales.

Plain Rat. (Mus lineolatus.) "Yar-lie" of the aborigines of the Darling Downs.

Gould"s Rat. (Mus gouldi.) "Kurn-dyne" of the aborigines of Moore's River, West Australia.

Little Rat. (Mus nanus.) "Jib-beetch"-aborigines of Moore's Rirer, West Australia.

Greyish-white Mouse. (Mus albocinereus.) "Noö-jee"-aborigines of West Australia, Perth District; "Jiip-pert"aborigines of Moore's River, West Australia.

New Holland Field Mouse. (Mus nova-hollandice.) New South Wales.

Delicatemcoloured Mouse. (Mus delicatuhus.) "Mo-lyne-be"-aborigines of Port Essington.

* This gigantie Rat lias a more or less spotted tail, which is without a brush at the tip. It is a now discorery, and Las becn doscribed as Itupulotis caudinnoulata by Ireffit, and under another name by Dr. Peters. It grows as large as the common Bundicoot-Perumeles nasuta. 



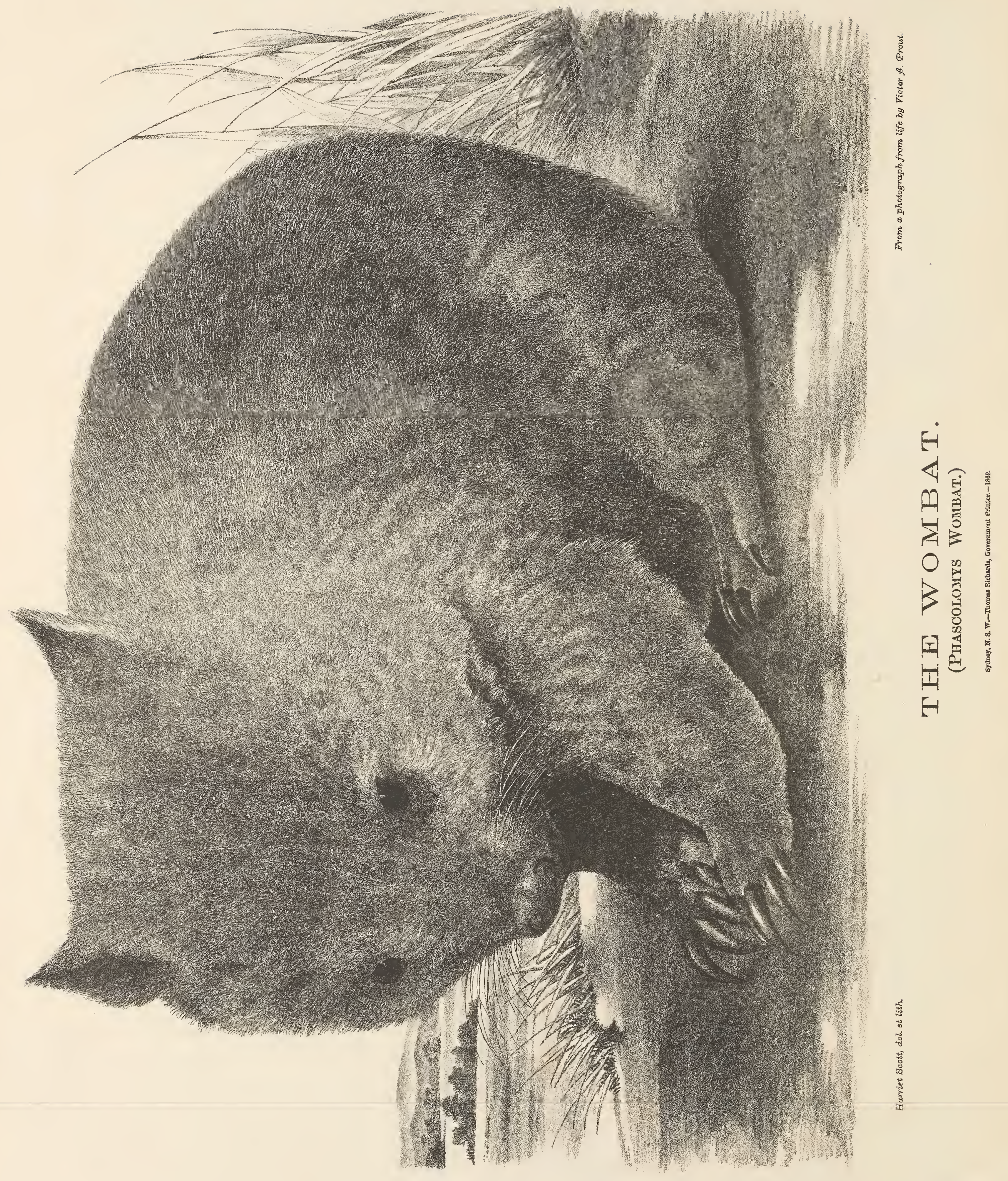




\title{
The 'Tasmanian Wombat.
}

\author{
(PHASCOLOMYS WOMBAT.)
}

Our figure represents the Tasmanian Wombat, which is rather smaller than the New South Wales species, but closely resembles it in the skeleton. The specimen which served as a model was a remarkably tame one. General colour dusky-grey or brown, more or less mottled with light hairs, so that the fur appears grizzly; lower part of the body greyish.

All Wombats have 24 teeth, arranged as follows:-Incisors $\frac{2}{2}$, premolars $\frac{I-T}{x-r^{3}}$ molars $\frac{4-4}{4-4^{\circ}}$ These teeth are without fangs, are more or less curved, and resemble the teeth of the common Hare. The food of the Wombat consists of grass, herbs, roots, young twigs, and other vegetable products, so that their flesh is palatable.

All the different species form extensive burrows, in which they pass the day, coming out to feed after dark. The female produces only. one young at a birth. The feet are constructed like those of the Phalangers or Opossums, to which family the Wombats are closely allied; the fore-feet have five toes, and the hind ones the same number, the inner or first toe being a small nailless thumb.

The pouch is directed upwards, as in the other marsupials that progress on all-fours, and contains four mammæ. () present species is peculiar to Tasmania and the islan's of Bass's Straits.

The New South Wales Wombat (Phascolomys platyrhimus) is found on the East and South Coast, extending even as far as Victoria, where also a brown rariety occurs. This castern Wombat differs little from the Tasmanian one, except that it is larger, and grows to over $80 \mathrm{lbs}$. in weight. Its colouration resembles the Tasmanian animal.

The third species inhabits the western parts of Victoria and the eastern border of South Australia. Fur sandy or yellowish, the muzzle covered with hair (all other species have this part of the hearl naked). Professor Owen was the first to point out the difference between this and the eastern species, and proposed the name "Broadfaced Wombat" (Phascolomys latifrons) for it.

A fourth variety, having brown or black, soft and silky fur, inhabits the neighbourhood of Port Lincoln, in South Australia; and for this animal the name of "Black Wombat" (Phascolomys niger) has been proposed. A rery fine specimen of this new species is in the Museum collection; and, having examined the skull, and compared it with that of the other Wombats, we have arrived at the conclusion that it is distinct. One very decided feature of the Black Wombat's skull is the great contraction between the orbits.

Wombats were much more numerous in olden times than they are at present, and varieties existed that were twice the size of our living species. We do not know how far these animals range to the north; the temperate regions of Australia appear to be their head quarters. They have not yet been observed on the West Coast. 




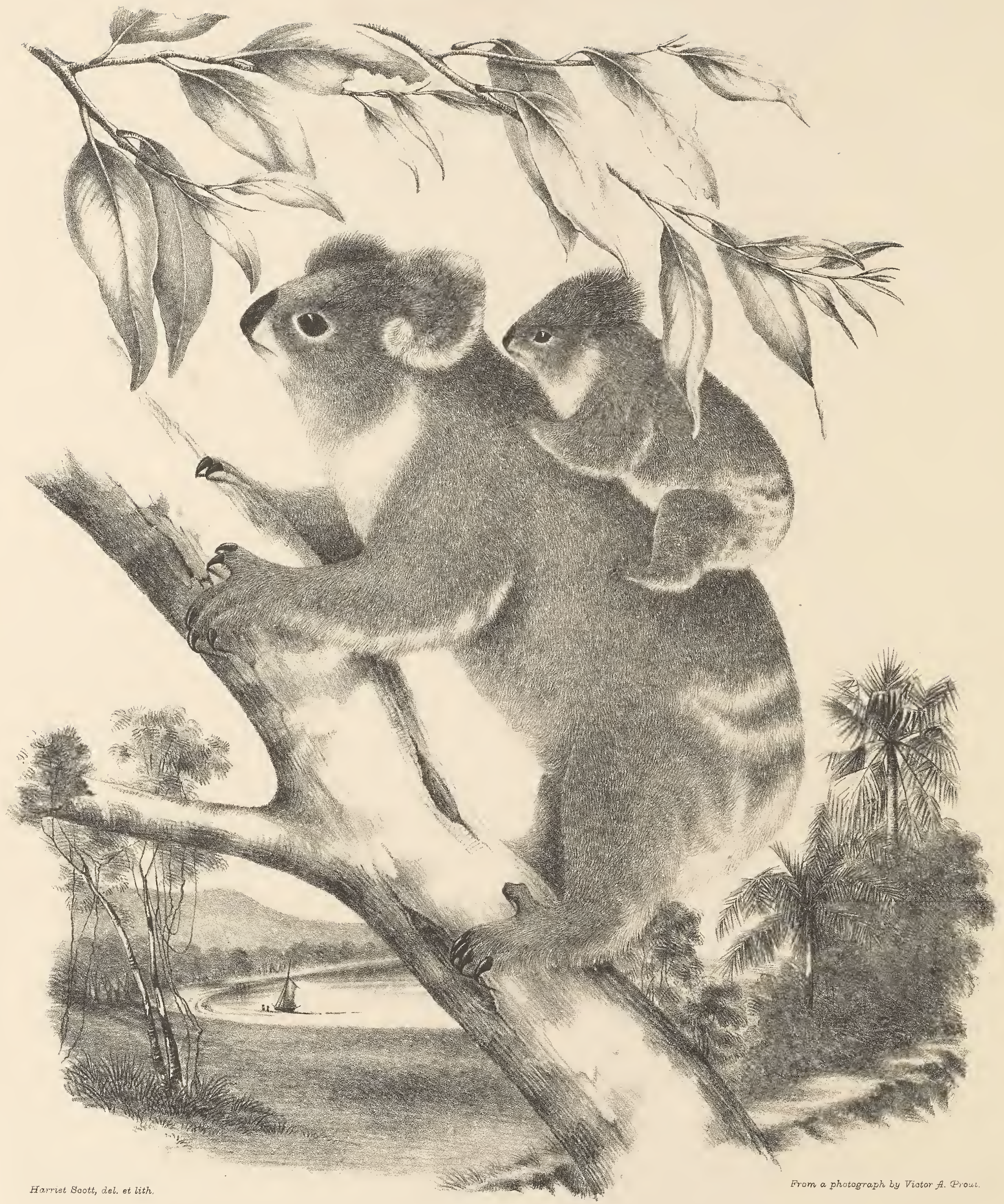

THE NATIVE BEAR.

(Prascolarctos Cinereus.) 


\title{
The Koala, or Native Bear.
}

\author{
- (PHASCOLARCTOS CINEREUS.)
}

THE animal figured in the accompanying plate, in the position of carrying a young one upon its back, is so well known to Australians that a short description will suffice. The total length is about two feet; the fur short and woolly, of an ashy-grey colour, more or less spotted with white near the haunches. The tail is so very small as to appear altogether absent, but in the skeleton ten flattish caudal vertebræ are observed.

The Koala, often misnamed "Native Bear," has no relation whaterer with the Bear tribe, but belongs to the marsupial or pouched section of the animal kingdom, and is closely related to the common Phalangers.

Comparing the general form of this animal with other members of the same group, we experience at first some difficulty in its proper classification; but having examined the hind feet, we notice a powersul prehensile inner toe or thumb, and observe that the next pair of toes, which are smaller than the others, are to a certain extent joined together by the skin. This construction of the hind feet determines the question, for it is peculiar to members of the Phalanger family-the Monkeys of the Marsupial Order, as they are often termed.

It must be remembered that the Phalanger tribe comprises all the animals which we usually designate "Opossums"; but as the true Opossum, of the fanily Didelphide, is peculiar to the American Continent, the term "Phalanger," sometimes applied to these animals, should always be used when speaking of "Australian Opossums." lt is necessary for the purpose of classification to examine the teeth carefully, and not to trust to the colour, texture, or length of fur only. Some authors lay great stress on difference in colour; but this is not a good characteristic, because animals vary constantly in consequence of climate, food, or locality. We all know, for instance, that the fur of the Native Bear, or Koala, is a light ashy-grey, in most parts of New South Wales; but those from colder regions, such as the south-eastern portion of Victoria, have a much darker fur. The result is that such specimens are often described a: new, while in reality they are only local varieties. The fur changes in length, thickness, or colour, under certain conditions; but the structure of the skeleton is so little affected by local or climatic influences that, for our part, we can only accept a decided difference in the bony frame or the teeth as decisive.

We noticed that the Koala belongs to the Phalanger tribe, on account of the structure of the hind feet. Let us now examine skull and teeth. In the upper jaw there are six front teeth, termed incisors; next to these is a slightly curred one-the canine; then comes a somewhat compressed and rather elongate premolar; and after that four teeth all equal in size, with their crowns divided into four parts--these are the molars or grinders.* 'The form of the molars indicates that the animal is herbivorous, though the presence of canines shows that its food may be varied by insects, eggs, or even flesh. As far as our experience goes, the Koala will not touch meat in captirity: and if its proper food-fresh young gum-leaves-is not provided, the creature soon pines away and dies. The Koala is nocturnal, and arboreal (or tree-living), and passes the day either sitting down with the head in its lap, or lying flat upon a branch, which is embraced by the powerful arms, or in some otler easy position, dozing away till the approach of darkness calls it to fresh activity. The difficulty of discerning the grey animal on a similar-coloured limb up a high tree is great indeed; and were it not for the protection thus giren to it by' the all-rvise Creator, this harmless creature would soon be externinated by its numerous enemies. The eye of the Koala is very small, of a light amber colour, and provided with a vertical pupil, which dilates after dark; the ears are large, and covered with bushy hair: the tail, as before stated, is apparently absent. The Koala is a powerful climber, and seldom comes to the ground.<smiles>C1=CC=C1</smiles>

* We would add, that the sraall 2nd and 3rd upper incisors are frequently lost, so that students might think the dentition given fo be incorrect. If they should find skulls with only two or four incisor teeth abore, they may rest assured that they hare to do will those of aged specimens, as the proper number of cutting teeih is six in the upper and twe in the lowor jaw. 
except indeed for the purpose of ascending another tree; its activity is, however, limited, and sereral specimens observed when in captivity were seen to sit down for a rest after every few steps. Old bushmen state that if a Koala is taken for a mile or two from its usual haunt, placed in captivity, and then liberated, it will run to the nearest tree, and remain there in preference to seeking refuge in a tree more remote or in the neighbouring forest, if there be one. Experiments have been made to test this, and the liberated "Bear" has been invariably found in the tree standing nearest to its late place of confinement.

The south-eastern part of Australia is the stronghold of these animals, the mountainous districts of Victoria and New South Wales are their most farourite localities; they are also found in Queensland to within the rery tropics, but always keep to the mountain ranges, and never visit the plains of the interior. They have a peculiarly harsh and shrill voice when angry, but are generally silent at other times, and very harmless.

The female seldom carries more than a single young one, which is born rery small-about the size of a French bean. The young, like those of other marsupials, do not suck at first, but the mother is provided with certain peculiar muscles which enable her to pump the milk into her helpless progeny. The question as to the mode of birth of marsupials has been much debated. They are believed by some to grow on to the teat. This is not the case, however, as they have frequently been found in the uterus. How they are conveyed thence to the teat will probably remain a secret for a long time to come.

The flesh of the Koala is not very palatable, owing to the nature of the animal's food. The skin makes exzellent leather, and good serviceable foot-mats.

The animal described as a Marsupial or Pouched Lion (Thylacoleo carnifex), and of which we know only a few fossil remains, is in reality allied to the genus Cuscus. Many other remains, in particular portions of the lower jaw, indicate clearly that a whole group of gigantic creatures has become extinct, and that nearly all of these-the Great Diprotodons, the Short-headed Zygomaturus, and the different species of the genus Nototherium-resembled the Koala or Native Bear more (in the structure of their limbs, the formation of the jaw, and the mode in which the teeth, are constructed and implanted) than any other Australian marsupial now living. 



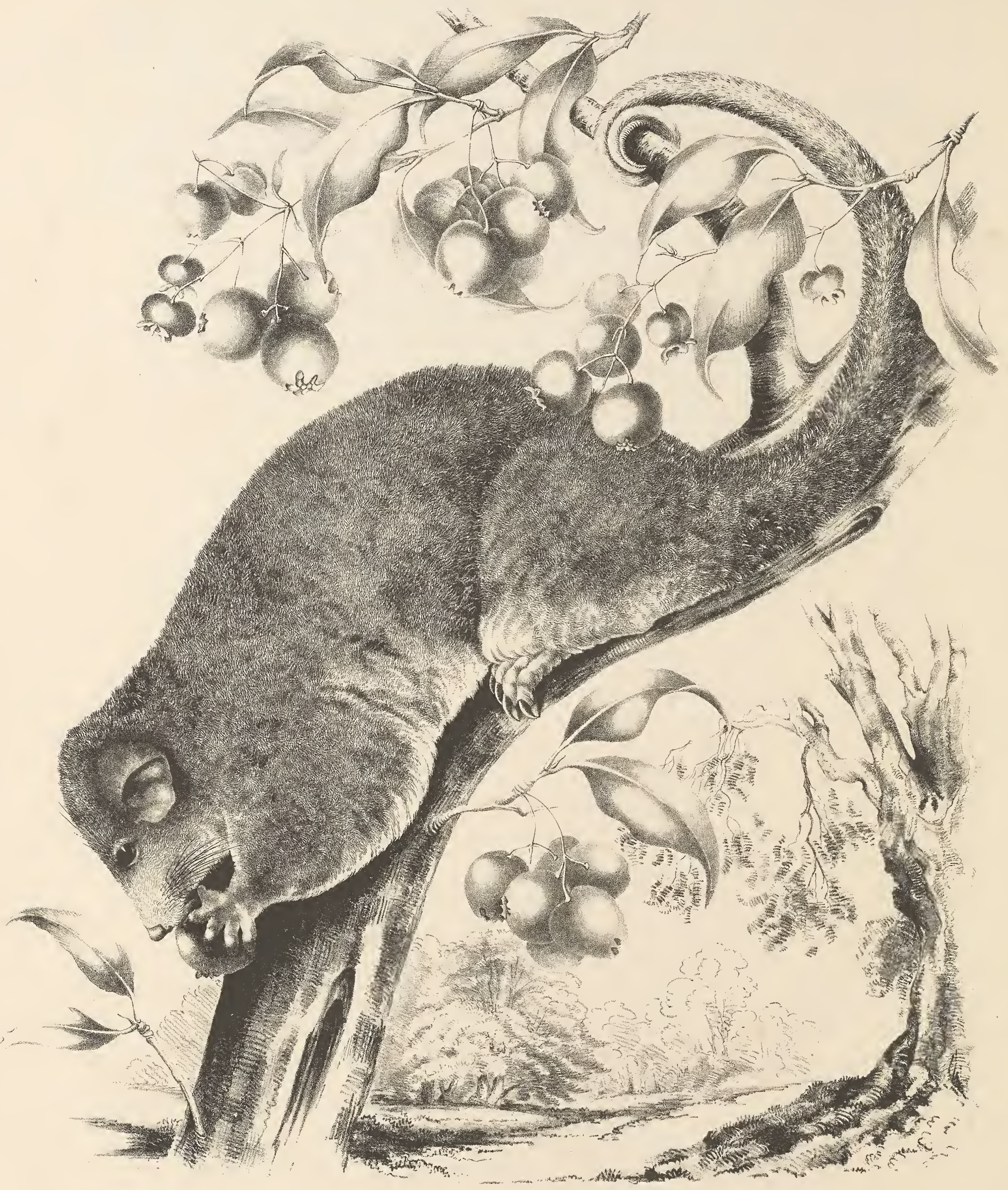

THE RING-TAILED OPOSSUM

(Phalangista Cooki.) 


\title{
Ring-tail Phalanger.
}

\author{
(PHALANGISTA COOKII. Desm.)
}

Fur dense, and moderately soft; upper parts of body grey, more or less suffused with red; flanks and outer surface of limbs bright rust colour, beneath whitish; ears short, hairy, sometimes with a white spot at the base; tail rusty at the upper part, which colour darkens to within a third of the total length, and ends in a white tip. The white portion of the tail varies considerably in different individuals, and is sometimes altogether absent.

The rusty-coloured Phalanger inhabits the east coast of Australia, and may be considered peculiar to New South Wales and the southern portions of Queensland.

A darker variety is found in Tasmania, and in other parts of Australia, extending as far as the Swan River Colony. The specimens obserred in New South Wales, west of the coast range, are generally much paler than the animals found in the dense scrub near the sea-boarl; there can be no doubt, however, that all the Ring-tailed Phalangers, of whatever colour, are varieties of one and the same species.

These remarks are based upon a careful examination of many skeletons and skulls from the localities before mentioned, and they must be considered far better characteristics than the colour of the fur or the length of the ears, which appear so important to superficial writers.

The Ring-tailed Phalangers are closely allied to the Petaurista or Great Flying Squirrel (or better Phalanger), much more so than may at first appear. The dentition of these two groups, in shape, number, and arrangement, is almost identical; but both differ considerably from the smaller Flying Phalangers-the well-known "Sugar Squirrels."

North Australia produces several species of Phalangers, which have a wide geographical range beyond New Holland; they belong to the genus Cuscus, and are distinguished by their remarkably short ears and partly nusle tail. The best known Cuscus is a large grey species, more or less spotted, the fur in texture and colour bearing a close resemblance to the fur of the Konla or Native Bear.

Returning to the southern Phalangers, it is pleasing to notice that the original "Phalanger of Cook" was one of the rufous-grey specimens of New South Wales, or what was then considered New South Wales, before the parent Colony had given birth to the prosperous divisions of Victoria and Queensland. The animal was discovered by Sir Joseph Banks on the Endeavour River, during Cook's first royage, and the second specimen which came to hand was obtained during the great navigator's last expedition, at Adventure Bay, in Van Diemen's Land. Years passed on, and more Phalangers, from other parts, had been brought to England, but all were considered to be one and the same species by the naturalists of the day, till Mr. Waterhouse, the most able writer on our Fauna, declared both animals to be specifically identical. It is necessary to enlarge upon this subject, because less painstaking autlors than Waterhouse are constantly dividing "Cook's Opossum" again and again, when they observe a new variation in the colouring; the last and most brilliant species being the "Victorian Ring-tailed Phalanger," but in truth only the dark variety of honest Captain Cook's own "Ring-tail." It is time for naturalists to take broader riews, and to cease confusing the many eager students who are only too willing to learn, but are constantly disheartened by empty discussions about dark and light hair and long or short ears, among the great Professors.

It is well known that all Phalangers are nocturnal in their habits, and Mr. Gould informs us that this particular species of Cook spends its days in the spouts and holes of the larger trees. Mr. Gould is not quite correct in this instance, as the animal much more frequently constructs a most beautiful covered nest among the slender branches of high trees, probably on account of the marauding propensities of the "Tiger Cats," it being no match for these ferocious brutes.

The female is provided with a well-forned pouch, containing four mamma, and the number of young seldom exceeds two. Mr. Masters took four young from the pouch of a specimen on one occasion; so large a number is, howerer, an exception. We will now give a general review of the group, as it comprises many species which are not figurerl in this work.

$(3 x, 11-11)$ 
FAMILY PHALANGISTIDA-(THE PHALANGERS.)

The animals forning this group differ considerably in their general habit and dentition. The normal number

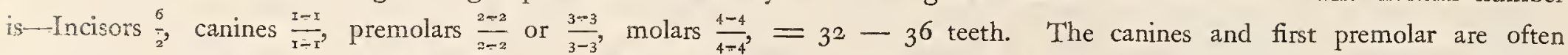
wanting. In the genus Phascolarctos the series is permanent, but reduced to 30 teeth, there being no lower canines, and but one premolar in each ramus. The pouch is present, well developed and downwards, the number of teats four, and the young produced at a birth generally one; but in the Ring-tail Phalanger litters of four have been noticed. The toes are five on the fore-feet, and five, including a nailless thumb, behind; the two inner toes are joined by a membrane, as in the Wombat or Kangaroo tribe. The Phalangers are found in almost every part of Australia, except the Koala or Native Bear, which is restricted to the east and south-east coast; and the members of the genus Cuscus, which inhabit only the tropics. The tail, generally so conspicuous and important, is absent in one species-the Koala, but in all others it is well developed and of great utility, on account of its being prehensile. We arrange the genera as follows:-

Genus Phascolarctos.-Phascolarctos cinereus. Native Bear, or Koala. Teeth:- Incisors ${ }_{2}^{6}$, canines $\frac{1-\mathrm{r}}{0-0}$, premolars $\frac{I-I}{I-I^{2}}$ molars $\frac{4-4}{4-4^{2}}=30$. Habitat-South-east and east coast.

Genus Cuscus.-Teeth:-Incisors, canines, premolars, molars, as given above $=32$ to 36 .

Tail with the basal portion only covered with hair; ears short, almost hidden by the fur of the head; eyes with a vertical, or nearly vertical pupil,

s. Cuscus maculata. Spotted Phalanger. Habitat-North Australia, Amboyna, Waigiou, Banda, and New Guinea.

2. Cuscus brevicaudatus. Short-tailed Phalanger. Habitat-North Australia, Port Albany,

Genus Phalangista.-Tail completely covered with hair above. Ears of moderate length. Teeth from 32 to $3^{6}$ in number.

1. Phalangista cookii. Cook's Phalanger. Ng̈̈-ra-aborigines of Perth, West Australia. Ngork-aborigines of King George's Sound. Habitat-The Phalanger of Cook (the first ever discovered in Australia) is restricted to the east and north-east, and does not occur in West Australia, as implied by the above aboriginal names. Mr. Gould, or rather Mr. Gilbert, probably refers to the Viverrine Phalanger, which is found on the West Coast.

2. Phalangista viverrina. Ring-tail Phalanger. Habitat-New South Wales (east of the coast range), Victoria, South and West Australia, Tasmania. The fur in this species is not red, as in Cook's Phalanger, but either grey or almost black. In young animals from West Australia the tip of the tail is red instead of white.

3. Phalangista laniginosa. Woolly Phalanger. Habitat--New South Wales, the Upper Hunter. This species from the Hunter is rare in collections, and may probably turn out to be a variety of Phalangista cookii. The fur is certainly more woolly, but without the examination of the skull no decision can be arrived at.

Genus Petaurista.

This genus is represented by a single species-the Petaurista taguanoides, or Great Flying Phalanger.

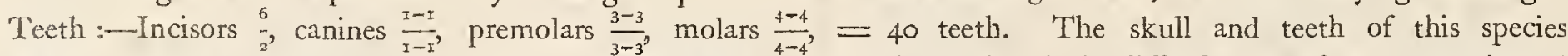
closely resemble the Viverrine and Cook's Phalanger, so much so that it is difficult even for an experienced anatomist to distinguish between the two when he has nothing but the teeth to go by. The skull of the Petaurista is, however, slightly shorter and more flattened. Only one species is known, which varies much, from creamy-white to spotted black and white and perfect black; beneath, the fur is always white. Iabitat-New South Wales, Victoria, and Queensland. This animal does not occur on the plains of the interior, and is restricted to the hilly country near the coast.

Genus Belideus.

There are a few characteristics by which the two genera of Petaurus and Belideus can at once be distinguished, and these are, more than anything else, the skull and teeth, so often overlooked even by what are considered standard authors. The skull of the Belideus flaviventer, which must be accepted as the type of the genus, is rounded, with large brain-case. (The skull of the Petaurista is flat, and contracted between the orbits.) The teeth (molars) are much smaller, not ridged, and they diminish from the first to the last; the lower incisors are of a totally different structure, considerably curved, and not scooped out as the teeth of Petaurisia, which animals move their mandibles like the Kangaroos. The teeth are:--Incisors $\frac{6}{2}$, canines $\frac{x-1}{1-x^{2}}$, premolars $\frac{3-3}{3-3^{3}}$, molars $\frac{4-4}{4-4^{2}}=40$. The genus comprises the following four species (a fifth, enumerated by some authors as Belideus notatus is a simple $B$. breviceps, which often occurs with a white tip to the tail):-

I. Belideus flaviventer. Yellow-bellied Flying Phalanger. General colour greyish-brown; beneath, white or yellow-white, sometimes even bright yellow. Habitat-New South Wales, Victoria, and Queensland,in particular the coast districts. 
2. Belideus sciums. Squirrel Flying Phalanger. Fur very soft; general colour delicate ashy-grey; a black dorsal stripe from nose to tail; beneath, white; tail very long, and bushy. Habitat-the north-east coast of New South Wales and the Queensland coast districts. Of the three smaller Flying Phalangers this species is the largest in size.

3. Belideus lreviceps. Short-headed Flying Phalanger. Colouration delicate ashy-grey, as in the preceding species; beneath, white; a dorsal stripe on the back, and a smaller and more cylindrical tail than Belideus sciurus. The present species inhabits New South Wales, Victoria. and probably South Australia. It prefers the mountain districts, and is not found on the plains of the interior.

4. Belideus ariel. Ariel Flying Phalanger. Wor-gi-aborigines of Port Essington. General colour as the two preceding species; beneath, rather more yellow; tip of tail black. This is probably only a variety of Belideus lreviceps. Habitat-North Australia, Port Essington.

Genus Dactylopsila. Tail elongate, slender, densely clothed with fur, with the exception of the under-side, near the tip; ears elongate, rounded, bald, except the outer side of the base; fore-feet elongate; toes very slender, compressed, very unequal in length, quite free; the hind feet slender, toes compressed, the two inner toes united-in fact, the feet of a Phalanger. The skull resembles that of Belideus facirenter, but the palate is narrower, and the orbital portion more contracted; the sagittal crest, which in Belideus is absent, is distinctly, but not much developed in the present genus; the zygomatic arch is weak in both animals, though much curved, and wide apart; the incisors above and below are strong, the lower ones bent upwards, rery powerful at the base, and as broal again as those of Belicleus, but the grinders are smaller. The correct formula is exactly as in Belideus fariventer. Incisors $\frac{5}{2}$, canines $\frac{1-1}{1-r^{3}}$, premolars $\frac{3-3}{3-3^{3}}$, molars $\frac{4-i}{4-4}=40$.

Dactylopsila trivirgata. Striped Phalanger. General colour white, with three broad black stripes. The mildle one runs from the head to the tip of the tail, which is black; the two outer ones enclose the eye, and send a branch down each leg; there is also a branch-stripe down the side of the neck. The habitat of this species is given as Aru Islands by Wallace. A specimen in the Australian Museum was obtained by Mr. J. A. Thorpe, at Cape York.

Genus Acrobates. The present genus comprises a single species, which is one of the smallest of the whole tribe The most important generic characters are the strongly developed canine teeth, the otherwise altered dentition, and the feathered tail.

Acrobates pygmoxa. Pigmy Acrobates, or Flying Mouse. Teeth:--Incisors $\frac{3-3}{x-1}$, canines $\frac{x-x}{1-x}$, premolars $\frac{3-3}{3-5}$ molars $\frac{3-3}{-3}=36$ teeth. General mouse-colour abore, white below; tail flat and feathered, not very prehensile; molar teeth as above, that is, two less in the upper and lower jaw than the other Flying Phalangers possess. Habitat-New South Wales, Victoria, and Queensland.

Genus Dromicia. The small Phalangers composing this genus have been likened to the Dormice amongst Rodents; they are, however, nothing more than small species of the Ring-tail Phalanger tribe, with the teeth arranged as in the last subject. Incisors $\frac{6}{3}$, canines $\frac{1-1}{x-1}$, premolars $\frac{3-3}{3-3}$, molars $\frac{3-3}{3-3},=36$. The ears are of moderate size, nearly naked, and generally carried folded down; the toe-nails are small, and the tail long, prehensile, and naked beneath. The upper canines and all the premolars are strongly developed, so that, with other characteristics, such as the habit of folding the ears, there is some approach to the small Dasyuride of the genus Phascogale, of which we shall have to speak hereafter. The genus comprises three or four species, which resemble each other considerably, though they are found in localities far apart.

Dromici gliriformis. The Thick-tailed Dronicia. The fur is of a mouse-colour, and whitish beneatli. This specimen has been figured very fat, with incrassated tail; but being taken from a pair of captives, it may be as well to state that when at large they are never in such excellent conclition. We examined several specimens from Tasmania, which appear to be identical with our own continental Dromicic unicolor. The King George's Sound Dromicia (Dromicia concinut) is probably distinct; it appears a more delicate specimen, with a clean white fur beneath; the upper surface is also of a mouse-colour, tinted or washed with brown. The Dromicias are found in New South Wales, Victoria, and West Australia they occur, no doubt, in South Australia and Queensland as well, but being so very small are seldom captured.

Genus Tarsipes. Head elongate and slender; muffle naked; mouth-opening small; tongue long, slender, with a brush at the tip; skull with the bones very thin and semi-transparent; lower jaw colisisting of - two slender rami without coronoid process, bearing a pair of horizontally-inserted incisors, with three tubercular teeth behind; in the upper jaw the canine is the largest. The dental formula is given by Waterhouse as follows :-Incisors $\frac{2-2}{2}$, canines $\frac{1-1}{0-0}$, molars $\frac{3-3}{3-3}$, or more. There can be no doubt that, through the Tarsipes and Myrmecolius, the Marsupialia are linked with the Monotremata, and in particular with the Echidna or Spiny Ant-eater (Echidnallystrix).

Tarsipes rostratus. Long-nosed Tarsipes. Fur short, adpressed, and rather harsh; general tint grey, more or less suffused with rust colour; sides of body distinctly tinted with rust colour, beneath rusty white; back, with longitudinal black lines; tail, dusky abore, greyish beneath, prehensile. Female with distinct pouch, four teats, and generally two young, of such small dimensions when born that they would pass through the eye of a large darning-needle. Habitat-King George's Sound, West Australia. 




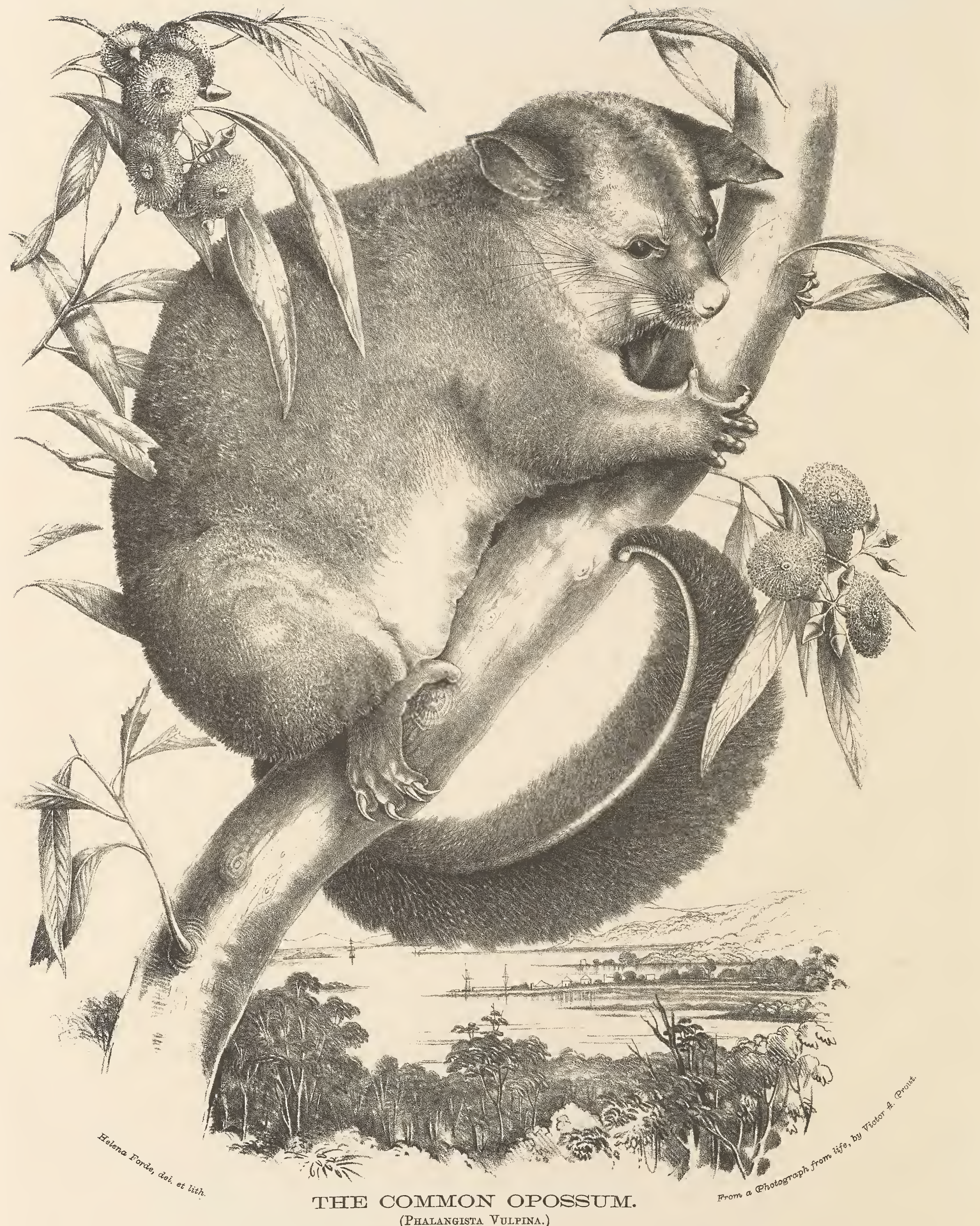




\title{
Vulpine Phalanger.
}

\author{
(PHALANGISTA VULPINA.)
}

THE subject of our present illustration is the most common and widely-distributed of Australian animals. It is classed with the Phalanger family, having the peculiar attributes of the tribe, namely, hind feet with a prehensile thumb, and two small inner toes, united by a membrane. The fore-feet are provided with the usual five strongly-clawed toes. The teeth differ constantly-the small ones at least between incisors and molars. The permanent set consists of three incisors, a canine, two premolars, and four molars, in the upper jaw; and one incisor, a very small tubercular canine, a premolar, and four molars, in the lower. In describing the dentition, the incisors, front, or cutting teeth of both sides are enumerated together; while the other teeth in each ramus are given separately. The usual way of expressing the dental formula in this case would be-Incisors $\frac{6}{2}$, canines $\frac{x-1}{x-1}$, premolars $\frac{2-2}{1-1}$, molars $\frac{4-4}{4-4}=34$. We stated that the teeth differ considerably in various specimens; because some retain the small premolars, and others shed or absorb them; their proper number would be $\frac{3-3}{3-3}$ above and below. In the majority of animals the dentition is, however, as above; two premolars in each ramus of the upper, and one premolar in each ramus. of the lower jaw. In order to test the correctness of our supposition that the number of premolars in each ramus really amounted to three, we obtained more than roo skulls, but amongst them only two were found with perfect dentition.

The colouration of the Vulpine Phalanger is as follows:-Fur long and woolly; ashy-grey, under-parts of body yellowish; muzzle and chin blackish; ears nearly naked on the inner side, well covered externally, except at the tip; a black patch at the base of the ear; feet yellowish, more or less suffused with brown. Old males have a rustycoloured neck and breast; tail bushy, black towards the apex, prehensile; and one-third of it naked beneath; eyes rather large, brown, with rounded pupil. Female with a well-developed pouch, four teats, seldom bearing more than one or two young at a time.

Numerous varieties of the common Phalanger exist in every part of Australia, from the far north to the islands of Bass's Straits and Tasmania; the black variety, with long ears, is peculiar to this island. In New Holland, or Australia proper, we find a Phalanger of a grey or black colour, and with shorter ears-in particular in the Clarence District-which has been described as a distinct species, under the name of Phalangista canina. A third variety occurs near the sea-coast, in thick stunted scrub about Port Hacking principally; the colour is sandy, and the tail less hairy than that of the species under review. This animal is said to inhabit the scrub only, and not to ascend trees.* It is captured by hunting with dogs, which drive it from the shelter of the thick brushwood where it passes the day, and it is thus secured without difficulty.

How far northwarl this variety is to be found we are unable to say. A few specimens in the Museum came from the neighbourhood of Port Denison, and were caught in localities similar to those which the animal frequents at Port Hacking. It is possible also that the, Phalangers that inhabit the Mallee-scrub are different from those which frequent high trees; the aborigines appear to think so, but in the absence of specimens we are unable to decide the question.

Settlers complain a great deal of the ravages of the Phalangers, and the increase is accounted for because their greatest enenies-the aboriginal natives-die off. Their food is varied; it consists of leaves, fruit, grass, and flesh. We have frequently observed them gnawing bones; and when they can get a small bird, or a nestful of eggs, they are not slow to take advantage thereof.

The day is generally passed in a hollow branch; only the Ring-tailed Phalanger constructs a sort of covered nest for its habitation.

Our figure, which represents the animal well in a natural position, is taken from a very tame half-grown specimen in the possession of the Hon. Henry Parkes, M.L.A. 




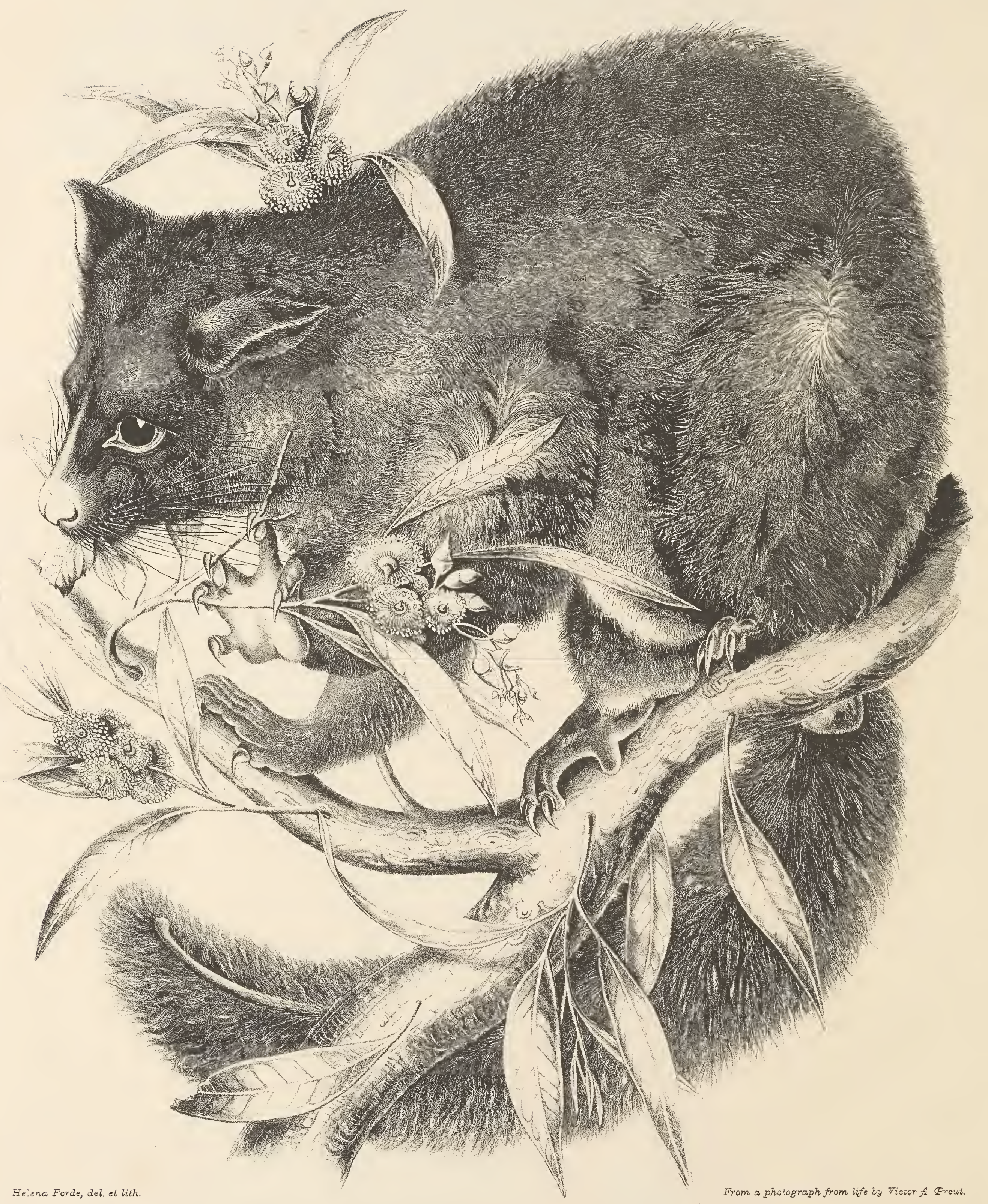

THE SOOTY OPOASUM.

(Phalangis'ta Fuliginosa.) 


\title{
'The Sooty Phalanger.
}

\author{
(PHALaNGista FUliginosa.)
}

THrs large Phalanger, a variety of the common mainland species, is peculiar to Tasmania, and either of the same colour as the Phalangista vulpina or deep sooty-brown, and occasionally almost black. The fur, however, is thicker and longer, and the darker skins are much valued for the manufacture of the famous Black Opossum rugs, which form a considerable item of Tasmanian exports. The dark variety is peculiar to the island, and not even found in Southern Victoria, where the colder climate would probably be congenial to its habit and economy, which are the same as those of the grey variety-the Vulpine Phalanger, better known as the common or "Brush-tail Opossum."

General colour brown-black, darker on the back; muzzle, chin, feet, and ears externally, black; throat, chest, and abdomen, of a fulvous brown colour-the last-mentioned part of a deeper hue than the chest, \&c. The ears are naked internally, or nearly so; externally they are well clothed with fur, excepting near the point and along the anterior margin, which parts are covered with small adpressed hairs. About six inches of the apical portion of the tail is naked beneath.

Mr. Waterhouse, than whom a better authority on our Mammalia does not exist, gives it as his opinion "that as the almost black specimens are sent from Tasmania, accompanied with others which are of very deep rufousbrown tint, much suffused with black on the back,-by others which are of a rich rufous-grey,-by others again which are grey, -and, lastly, by individuals, which are of a crean colour, - and as all these specimens agree very closely in size and proportions, - we can but conclude that they form one and the same variable species. Upon comparing the skins, or stuffed specimens, of this Tasmanian Phalanger, with those of the Phalangisla vulpina of New South Wales, the only tolerably constant difference which could be perceived was that the island animal was larger than that of the mainland, and two skulls of Tasmanian specimens presented a corresponding difference of size when compared with the crania of the common P. vulpina." Our own investigations corroborate Mr. Waterhouse's opinion. There is a difference in size, and some slight alteration in the position of the teeth, but these characteristics may only belong to certain individuals, and probably occur in mainland specimens also. It would be interesting to secure a series of young of the dark variety, and compare them with the young of the light-coloured species. If really different, these dark-coloured animals would show indications of it even before the hair has appeared; and we shall prove hereafter, when speaking of the Kangaroo tribe, that certain places which, in the adult animal, are covered with black hair, are marked accordingly in the naked young.

The aborigines of Tasmania are now extinct, and the Phalangers have no other enemy except the Tiger Cat, or Tasmanian Dasyure, and civilized man; but with all the scientific weapons at their command the hunters cannot perceptibly diminish them. On the mainland these animals have become a perfect pest in some districts. Their nocturnal and arboreal habits, their food and number of young, are well known, and are the same as those of New Holland. 




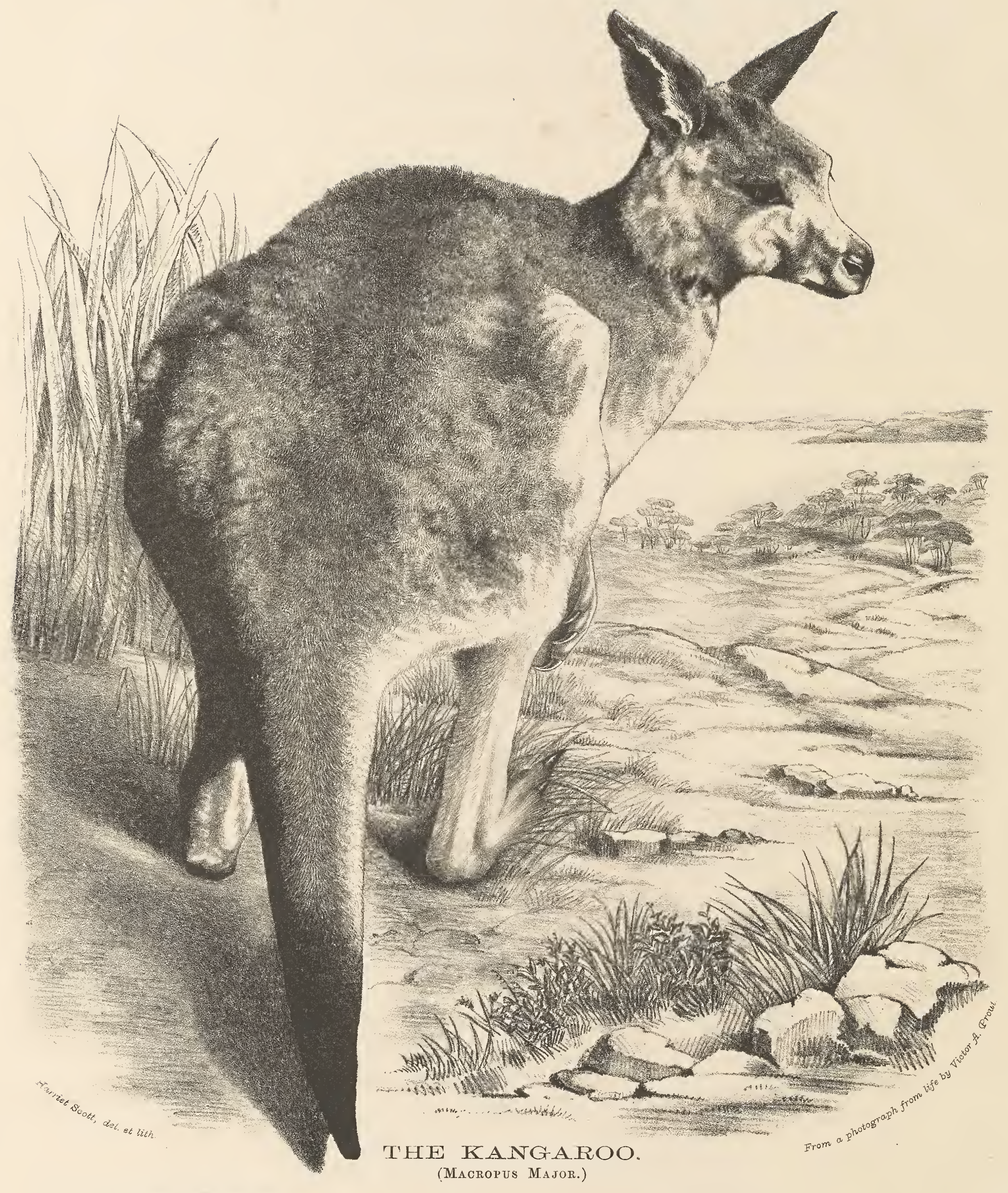




\title{
Great Kangaroo.
}

\author{
(MACROPUS MAJOR. Foung Mrale.)
}

IT is just a century since Captain Cook discovered the Common or Great Kangaroo in the neighbourhood of Port Jackson, and notwithstanding all the persecution by man and $\operatorname{dog}$ these large Marsupials still hold their ground.* From the vicinity of the City they have certainly disappeared, but in the Port Hacking District, on the south side of Botany Bay, a few may yet be found. The nearest spot where good sport can be obtained is Jervis Bay, to which locality regular hunting parties proceed, and generally return with good "bags" or rather "cart-loads" of game.

The distribution of the Great Kangaroo appears to be confined to Tasmania and the southern portions of the mainland; the animal does not occur on the West Coast, where another allied species (Macropus ocydromus) takes its place, nor do we remember that the Common Kangaroo has been observed very far north.

In some districts the settlers are obliged to have regular battues to keep the Kangaroos within bounds, because they feed voraciously and multiply so quickly that sheep or cattle would soon be outnumbered by them. The main cause of this prolific increase is no doubt the destruction of the Native Dog and the absence of the aboriginal hunting parties. The fur of the Kangaroo is rather short and woolly, the prevailing colour a brownish grey, the under side of the body, inner parts of legs and the arms being lighter; the tarsi and toes are black. The male exceeds the female in size, but there is no difference in the colour of the sexes.

When a herd of Kangaroos is disturbed, the old males keep in the rear, the fleeter females and young going off first; and it is astonishing to see the large space of ground they cover at a single bound when hotly pursued. Few artists have however attempted to illustrate the precise way in which these animals progress; even our best authors represent them as running like greyhounds (See Gould's "Mammals of Australia," plate 34), but if really they attempted to do so they could not avoid going "head orer heels."

The whole tribe progresses by a succession of jumps, using the hind legs only, and the tail to balance the body; the arms are pressed close to the chest; the heavy tail forms a gentle curve, but never touches the ground; and the two elastic tarsi come down together at regular intervals with a heavy thud. When feeding on short herbage the arms and hands rest on the ground, and the tail with the hind legs form a sort of tripod. In this fashion the Kangaroo moves by raising the tarsi (the body resting on the tail and fore-legs) and pushing them forward.

Few animals are more graceful when' running than those of the Kangaroo tribe; but, as we mentioned before, artists will not take the trouble to observe them, and the consequence is that, when a sketch is'attempted, a caricature is the result. We appeal to the rising generation to study nature, and trust they will learn to draw a Kangaroo as carefully as they learn to draw a Horse or a Dog, and that they will discontinue to accept as correct the ludicrous representation of the animals which have hitherto supported the Australian Shield under the names of Kangaroo and Emu.

* We caution students against placing implicit belief in the statements of foreign writers about Australia, let the name of the author be ever so much respected. Mrs. Somerville, in her famous book, "Physical Geography," in the fouth revised edition to loot, tells us that the pouched tribe (p. 472) vary from the size of a large doo to a mouse; that the Banded Kangaroo is found only in the islands in Shark's Bay, on the West Coust of New South WVales; that there are only fifty-thrce species of terrestrial Mammalia in Australia altogether; that the rodents are all aquatic, and very peculiar; and that the Phalangers burrow in the sand. We are also informed that the Kangaroos have become scarce near the British Colonies, and that the whole of the native animals are likely to be soon extirpated. (With Wallaby skins by the thousand, at 3 d. each.) We conclude with an extract from page 269:- "The Macquarie is called the Fish River between Battiurst unul Sydney." 




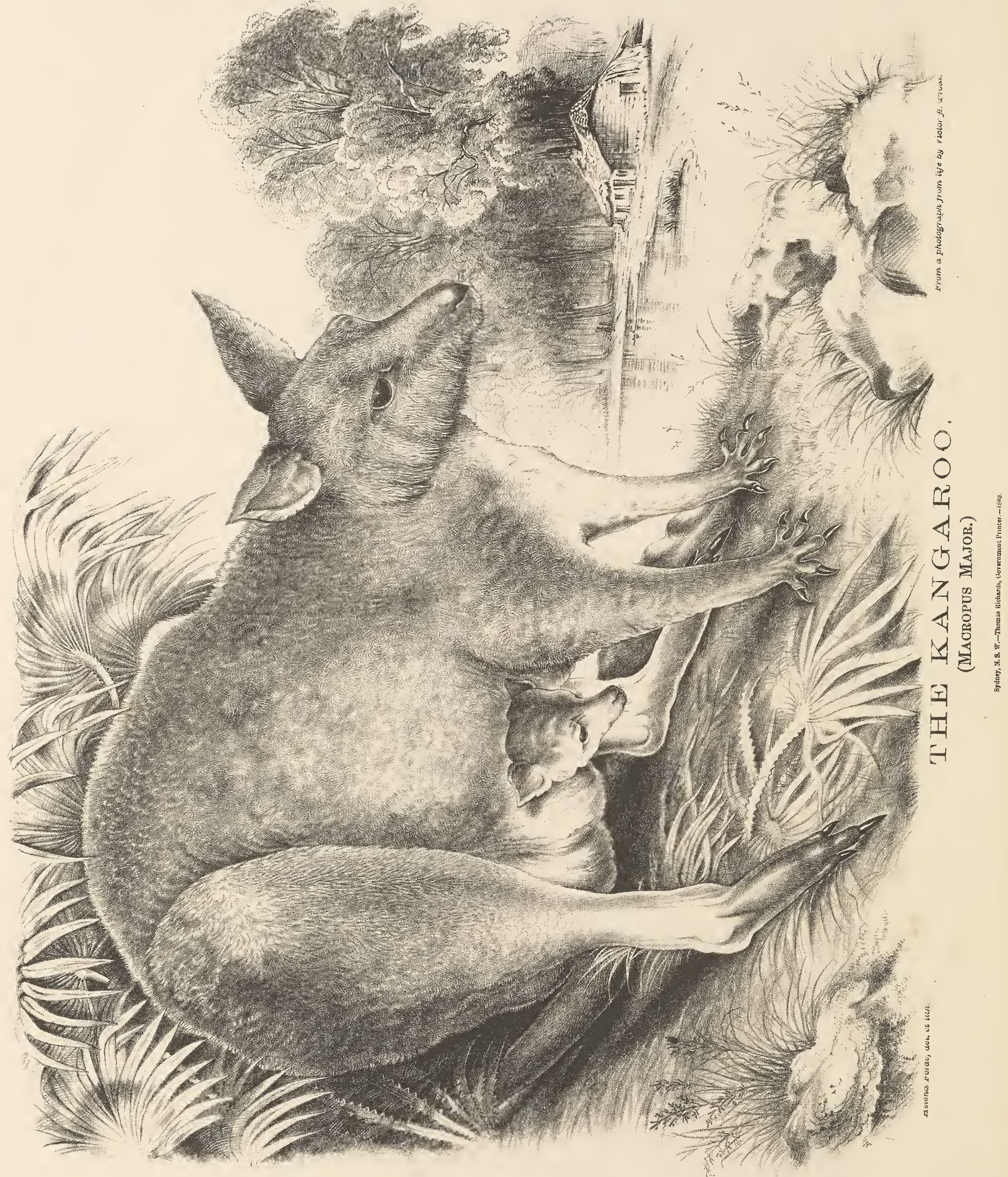




\section{Great Kangaroo.}

(MACROPUS MAJOR. Female, with young.)

THE animal here represented is the female of the common or Great Kangaroo, which has been already described, and we take this opportunity to review the whole family, comprising the following natural groups or genera:-

Great Kangaroos (Macropus); weight of animal up to 200 lbs.

Wallabies or Brush-kangaroos (Halmaturus); weight from to to 50 lbs.

Rock-wallabies or Rock-kangaroos (Petrogalea); weight up to $30 \mathrm{lbs}$.

Tree-wallabies or Tree-kangaroos (Dendrolagus); weight up to $30 \mathrm{lbs}$.

Silky-haired or Nail-tail Kangaroos (Onychogalea); weight from 8 to ro lbs.

Hare-kangaroos (Lagorchestes); weight from 6 to $8 \mathrm{lbs}$.

Bettongs or Jerboa Kangaroos (Bettongia); weight from 4 to 5 lbs.

Hypsiprymni or Rat-kangaroos (Hypsiprymmes); weight from 2 to 5 lbs.

\section{THE GREAT KANGAROOS-(GENUS MACROPUS.)}

First and second upper incisors rather feeble, third very broad, with two slight vertical folds.* Permanent premolar small, and soon lost; molars pushed gradually out, so that the normal number of molar teeth $\frac{4-4}{4-4}$ is never found perfect in aged animals. The teeth are always irregular, and are frequently retained longer in one ramus than in the other. When the last molar has come into position, the dentition may be considered complete, and would stand in this way :incisors $\frac{6}{3}$, premolars $\frac{\mathrm{t}-\mathrm{I}}{\mathrm{y}-\mathrm{I}}$, molars $\frac{4-4}{4-4},=28$ teeth. The skull is rather broad between the orbits, rounded above the anterior portion of the zygoma, and the space between the grinders and the incisors rather longer than in the smaller Kangaroos. The arms are strong, but appear "small from the elbow to the wrist, on account of their being covered with short adpressed hair. The tail is long, very powerful, and forms a strong support to the body,

It is difficult to say how far the common Kangaroo ranges. northward,-probably not much beyond the tropics. The West Australian Kangaroo is a distinct species.

Westerin Kaygaroo (Macropus ocydromus).

This animal, which at first sight appears identical with the common Kangaroo, is of a smaller size; its limbs are finer, and the fur shorter but more woolly. The colour is slightly darker, and the legs white, or nearly so. It is peculiar to West Australia.

\section{Sоoty Kingaroo (Macropus fulliginosus).}

Little is known of this species, which was first discovererl by French voyagers on Kangaroo Island, where it is not now to be found. The fur is longer, more yellowish, and has a more woolly texture than the fur of the Great Kangaroo.

\section{Red Kavgaroo (Macropus rufusj. +}

The male is rich orange-red, with the legs and abdomen of a light yellowish-white; throat and chest delicate pink. This colour is very deep during the rutting season, and appears to be a sort of pigment excreted from the body. We have often examined old males a short time after death, and have also kept others in an enclosure, and in every one of these animals the colouring matter of the neck and breast marked the fingers when these parts were touched. When some of the tame animals were driven about and had exerted themselves violently, the colouring became more apparent, and a peculiar odour, not unpleasant however, was also noticed.

The teeth are slightly different from those of Macropus major; the stronger premolar is not pushed out; but having examined only a few skulls of adults we cannot say whether these characteristics are constant.

The Red Kangaroo inhabits the interior of New South Wales, Queensland, and South Australia. The female is bluish-grey; legs and abdomen white. Weight of male about 200 lbs.

* These folds or grooves become obliterated with age.

† Those authors who are fond of nuking genera without giving proper reasons for so doing, arrange the Red Kangaroo with the genus Osphranter, -We believe on the strenguh of its "hairy nose." If a division is desirable, let those animals be comprised under the genus $O_{\text {sphranter }}$ of which the sexes differ in colour.

$(30014-71)$ 
RED WaLLARoo (Macropus antilopinus).

Male.-Fur short, the hairs stiff, and closely applied to the body; limbs and abdomen pale rusty-yellow; toes black; height, about 4 feet. Female.-Considerably smaller; fur longer, less harsh, and less closely applied to the body than in the male. General tint brown, under-parts and limbs rusty white; fore-feet brown, with black hairs near the claws.

Mr. Waterhüise states that the skull of Macropus antilopimus is about equal in size to that of M. major, but shorter in proportion to its width; and the most striking difference is in the form of the muzzle, which, instead of becoming gradually narrower towards the apex, is quite as broad near the end as at the base, and is broadest rather in front of the middle; the nasal bones are shorter than in $M$. mujor. The frontal bones are deeply concave above between the orbits, and are much contracted immediately behind them; the temporal ridges meet to form a well-marked sagittal crest. The foremost incisor is but little broader than the second; the third is about double the width of the second, has a strong oblique external groove, rather in front of the middle of the tooth, and there is a second groove in front of this; but this latter, which represents the foremost of the two grooves observed in Macropus major, is much less distinct than in that animal. In an adult, or rather aged indiviciual, Mr. Waterhouse observed only i 3 molar teeth in both jaws, - - a proof that this animal has been correctly arranged with the Kangaroos proper, in which the teeth are variable, and are pushed from behind forward and out.

The habitat of this species is given as Port Essington, where it was discovered by the late Mr. Gilbert. Weight of male from $x_{50}$ to $200 \mathrm{lbs}$.

BuAck WaLiaroo (Macropus rolustus.).

Male-Fore and hind legs rather short, but powerful. General colvur decp slaty-grey; legs and toes black. Female.-Much smaller than the male. General colour silvery-grey; beneath and legs whitish; toes brownishblack. Weight of male, I 50 lbs.

Habitat.-The mountain ranges of the Coast of New South Wales.

Animals from to to 50 lls. weight.

\section{BRUSH-KANGAROOS-(GENUS HALMATURUS.)}

Kangaroos of moderate size, with slender, sometimes very short arms, and rather eiongate tail. Skull comparatively shorter than that of the Great Kangaroos. The teeth the same as in Macropus. The principal distinguishing characteristics are the third upper incisor and the permanent large premolar. The third incisor is more elong: ${ }^{+e}$, with rather a narrow crown and a deep groove; the corresponding tooth of a Macropus has a broad crown, and the groove is often obliterated by the time the adult state is reached; in young animals it is always better developed. The premolar is permanent, and seldom lost except perhaps in extreme old age. The molar series wears down instead of being pushed forward, so that the dental formula is constant. Incisors $\frac{6}{2}$, canines $\frac{0-0}{0-0^{2}}$, premolars $\frac{t-1}{t-1}$, inolars $\frac{4-4}{4-4^{2}}=28$. All Wallabies or smaller Kangaroos (with very few exceptions) have a bridle-mark behind the shoulder and a horizontal stripe across the haunch. There is not much difference in colour and size between male and fenale, and their habits are more or less nocturnal. The largest species live in Tasmania; the smallest are found in New South Wales and in West Australia.

\section{Parry's Wallaby (Halmalurus parryi).}

This is one of the fleetest and most slender-footed of the whole tribe; its tail is very thin and long, the arms are rather powerful, and the general colour is silvery-grey above and white beneath; there is the usual black mark from the eye to the muzzle, bridle and haunch marks are indistinct; the toes are black.

The habitat of this species is New South Wales and Qucensland; it first occurs in the Clarence River District, and is common at Wide Bay and on the Burnett and Dawson. 



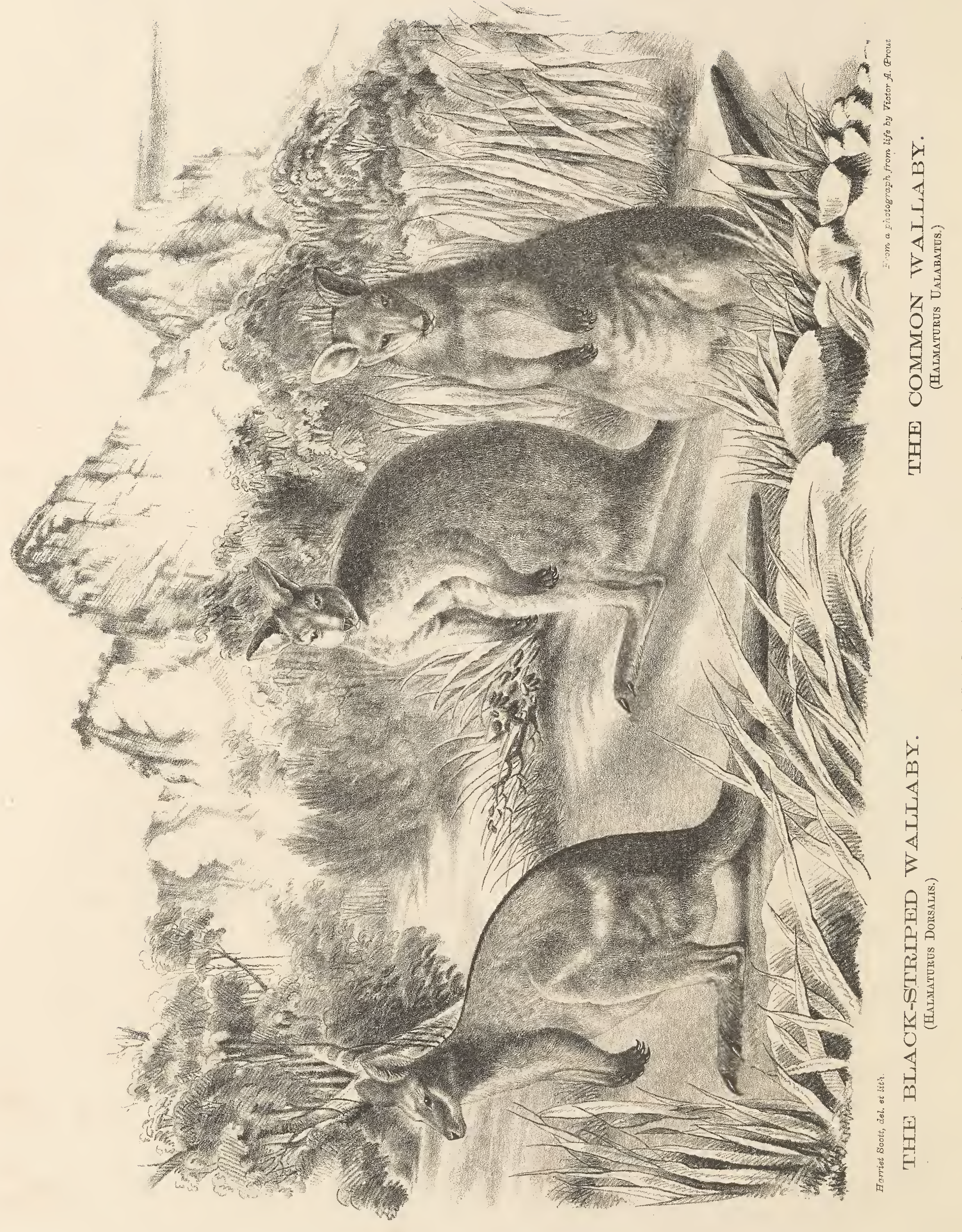


BLACK W WLLABY (Halmaturus ualakatus).

Fur of moderate length, rather harsh and glossy; general colour deep brown, suffused with reddish on the hinder parts of the body; feet and tail very dark, almost black. Abdomen and breast rusty yellowish. The Black Wallaby, or Black-tailed Wallaby as Mr. Waterhouse designates this species, inhabits the eastern parts of Nẹw South Wales, principally the Coast Range, extending northward as far as the Clarence and Richmond, perhaps farther. An allied species to which the name of Halmaturus Mastersii has been given, occurs in some of the Queensland Districts at the Burnett and other rivers. This variety is lighter in colour, but sufficient specimens have not yet come to liand which would prove that the light colouration is constant.* In the neighbourhood of Sydney no other but the Black Wallaby is found. The structure of the skull resembles H. ruffcollis; the third or inner upper incisor is very large, with a deep groove and rounded outer margin; the premolars are thick and very permanent; that is, not easily lost or worn down. The tail is long, not much incrassated at the base, and less stiff than other Wallabies have them; in fact, the form approaches the pliable tail of the Rock Wallaby (Petrogalea).

BLACK-striped WALLABY (Halmaturus dorsalis).

Fur rather short, general colour grey with a wash of brown; neck and shoulders rust colour, beneath white; toes black; a black stripe from the neck to near the tail. The skull is rather elongate, and resembles $H$. rufcollis. The teeth are very irregular, and of eight or ten adult specimens examined not two are alike, so that it would be vain to attempt a description. The animal is smaller than H. ruficollis, and inhabits the districts of Southern Queensland; it is also found in the north-eastern parts of New South Wales.

\section{RED-NECKED W WLLABY (Halmaturus rificollis).}

Fur of moderate length; general colour rusty-grey, under parts grey-white, slightly suffused with pale rust colour; ears whitish internally, tipped with black; tail rather long, greyish, with black apex; toes black.

It is stated that this Wallaby was first discovered by the French naturalists in King's Island, Bass's Strairs, and that it was found even in the neighbourhood of Sydney. The first statement we doubt very much, and why it should not be found near Sydney now is inexplicable. The Black Wallaby is as plentiful as ever, and this is the only species which old residents remember to have hunted since they were boys. The fact is; all these supposed species vary so much in colour that it is really out of the question to give a description which will answer to every variety. We will just examine the red-necked Wallaby, and record a few facts.

Mr. Gould gives some good figures of the animal, which answer to a variety from the Clarence River. The "Bong Bong" variety, lately discovered by Mr. Masters, is of a more grey colour, no rust-marks are visible on the neck. A white stripe on the haunch is present in one specimen, but this is wanting in the others. The face-markings differ also in the four specimens in our collection. Only one young has the white stripe under the eye as distinct as Mr. Gould figures it; an old male has the whole face blackish, with just a shade to indicate the white mark seen in the young. A full-grown female shows a similar shaded stripe and a small light patch on the corner of the mouth, so that it is extremely difficult to give more than a general description without creating confusion. Both Mr. Waterhouse and Mr. Gould consider Halmaturus bemettii of Tasmania to be only a variety of the present species. In outward appearance both animals differ much, H. bennettii being almost uniform dark-mottled grey, with shorter legs and tail; but having compared a series of skulls of both, we come to the conclusion that there is no specific difference, as far as head and teetl are concerned. The fact is, all these Wallabies interbreed, in captivity at least.

BLACK-GLoved WALLABY (Halmaturus manicains).

General colour grey, aistinctly pencilled with black and white, under parts pale grey, slightly suffused with yellowish. Legs and feet yellow, except the fore-part of the latter, which is black, the two colours being sharply defined. Arms short and slender, ears tipped with black, tail long, compressed, not very thick, with a crest of black hair on the upper and under surface of the apical half. The bridle-mark is indistinct or absent, but there is a series of black stripes across the back and haunches resembling the markings of the Banded Hare-kangaroo. As no author has mentioned these marks before, we wish to draw attention to them.

* Mr. Masters has lately collected a fine series of these Wallabies on the Burnett River, in Queensland; and though skull and teeth differ little, except in the smaller third uniprr incisor, from those of the Black Wallaby, the reduced size of the fore-limbs proves it a distinct species. The colour is iron-grey, with rusty hairs interspersed, a rusty-coloured belly, and a black short bridle-mark behind the shoulder. 
The skull resembles the skull of a Hare-kangaroo (Lagorchestes); it narrows suddenly in front of the zygoma, is deep vertically, furnished with a slender canine, and has the first upper incisor large and strong, exactly as the Lagorchestes leporoides. West Australia is the habitat of this Wallaby.

A Queensland species, of a sandy colour.

Agile Kangaroo (Halmaturus agilis).

This concludes the list of the larger Brush Kangaroos or Wallabies up to $50 \mathrm{lbs}$. weight. The following species are much smaller.

BRUSH KANGAROOS-(GENUS HALMATURUS)-up to $30 \mathrm{lbs}$, weight.

H. Greyi. South Australia.

"Derbianus. South Australia.

" Hautmanni. Hautmann's Abrolhos, West Australia.

PADEMELONS, OR SMALL KANGAROOS-(GENUS HALMATURUS)-from to to 15 lls. weight.

II. parma. East coast of New South Wales.

" dama. West Australia.

" thetides. Coast districts of New South Wales.

" billardieri. South coast districts and 'Tasmania.

"stigmaticus. North-east coast.

" brachyurus. West Australia.

"wilcoxi. Clarence District and Southern Queensland. the interior.

These animals inhabit the mountain districts near the coast, and are seldom if ever found on the plains of

ROCK-WALLABIES, OR ROCK-KANGAROOS-(GENUS PETROGALEA)-with long pliable tail not incrassated at the

base, inhabiting mounain districts on the southern, eastern, and western coast line. (Weight of animal up to 30 lls.)

Petrogalea penicillata. Eastern parts of New South Wales.

" inornata. Eastern parts of New South Wales.

" xanthopus. South Australia.

" brachyotis. West and north-west coast.

" lateralis. West and north-west coast.

9. concinna. West and north-west coast.

STRONG-ARMED KANGAROOS, OR TREE-KANGAROOS-(GENUS DENDROLAGUS.)

D. ursinus. New Guinea.

" inustus. New Guinea,

These animals ascend trees, and are distinguished by their powerful fore-limbs and long pliable tail, which resembles that of the Rock-wallabies. A third species (Dorcopsis truni) also inhabits New Guinea, but is terrestrial, though the fore-legs are more strongly developed than is usual in Kangaroos. The weight of these animals we should jurge to be about 30 lbs. The $D$. brumi was the first Kangaroo ever discovered-many years before Cook's voyages.

SILKY-HAIRED, OR NAIL-TAIL KANGAROOS-(GENUS ONYCHOGALEA.)

O. unguifer. North-eastern parts of Australia.

" frænata. Plains of the interior of New South Wales and Victoria.

" lunata. Plains of the interior of South and West Australia.

This group comprises the small silky-liaired Wallabies or Kangaroos of the interior; they weigh seldom more than 8 or 10 lbs., and are about the size of a common hare. Their light-grey fur is of a peculiar softness, and the tail has a bare nail-like tip. This genus and the following genera possess more or less developed canine teeth.

L. fasciatus. West Australia.

HARE KANGAROOS-(GENUS LAGORCHESTES.)

, hirsutus. West Australia.

" conspicillatus. West Australia.

" leporoides. Plains of New South Wales, South Australia, and Victoria.

, leichhardti. North-east coast and Victoria. 
The Hare-kangaroos, so called from their resemblance to that well-known rodent, are the fleetest of the whole tribe; and though they do not exceed a common hare in bulk, they can make clear jumps of eight and ten feet high. Their arms are exceedingly short, and when progressing cannot be noticed, because they are pressed close to the body, and covered by the long fur; the hind legs are very long and slender, and the tail rather short and stiff, and not incrassated at the base; the canines are well developed.

BETTONGS, OR JERBOA KANGAROOS-(GENUS BETTONGIA.)

B. cuniculus. Tasmania.

"greyi. New South Wales, South and West Australia.

, campestris. South Australia.

These three species of Bettongs resemble each other very much, and are probably nothing but varieties. The western and southern animal, that is B. greyi and B. campestris, form extensive burrows, which the Tasmanian species does not; the tail is more or less prehensile, and the weight ranges from 5 to 6 lbs.

B. penicillata. Interior of New South Wales.

" ogilbyi. West Australia.

These two animals also resemble each other; they are very small, probably not more than 3 or 4 lbs. in weight; the tail is prehensile, and they climb well. We have seen one get over a close palisade-fence 8 feet high. This group connects the Kangaroo-tribe with the Phalangers.

\section{RAT-KANGAROOS-(GENUS HYPSIPRYMNUS.)}

H. murinus. New South Wales.

" apicalis. Tasmania.

" gilberti. West Australia.

" platyops. West Australia.

The true Rat-kangaroos approach the Bandicoot tribe, and some naturalists have classed them as Bandicoots when the skull could not be examined; their limbs are of more equal length; they progress rather slowly, and the tail is short and stiff. The head of the Rat-kangaroo is elongate, that of $H$. platyops excepted; and the canine teeth are strongly developed.

\section{BANDICOOT TRIBE-(PERAMELIDA.)}

(Wilhout illustration.)

Having closed the Kangaroo family with the Kangaroo Rats proper of the genus Hy/pisiprymuzs, we cannot but notice in the Bandicoots a general resemblance to the Rat-kangaroos. The Bandicoot family differs, however, much from all the preceding ones in the larger number of teeth. The usual formula, from which the Wombat only deviated, of six cutting teetl or incisors above and two below, has disappeared in the present section, and we find the incisors increased to ten above and six below. The fore-feet have the outer toes rudimentary, with only three nails, and the hind feet (though they retain the Kangaroo characteristic, and still possess the two inner toes joined by an integument) begin to produce a yet very rudimentary fifth toe or thumb. The pouch of the female, owing to its peculiar mode of progression, reassumes the reverse position to that of the Kangaroo and Phalanger tribe, and again resembles the pouch of the Wombat with its opening upwards. The number of mamma is changed, however; we now find eight instead of four, though the young never exceed four. The tail of the Bandicoots proper is short, and the fur harsh to the touch; their food comprises bulbous roots, grass, and insects; they are excellent as destroyers of vermin, and we have noticed fifty and more mice killed by one of them in a very short time.

The family comprises three genera:-

\section{Genus Peragalea.}

Head very elongate, canine teeth, powerfully developed grinders conical and almost rootless, with nothing but a few tubercles at the lower part of these teeth; tail large, compressed, with a crest of hair on the upper edge, ending in a considerable tuft.

Rabititenami Peragalea or Rabbit-Ra't (Peragalea lagotis).

This animal, which is about the size of a rabbit, has also very long ears, and beautiful silky ashy-grey fur; the skull is much contracted between the orbits, and furnished with curved canine teeth of great strength. The animal 
feeds on bulbous roots principally, and is not so ferocious as these tusks would indicate. The upper end of the tail is black, the remaining half covered with long white hair; the under part of the body is whitish. This is the only member of the family which burrows in the ground.

Habitat-New South Wales, Northern Victoria, South Australia, Queensland, and West Australia.

Genus Choropus.

Head very broad, skull much contracted between the orbits, as in the preceding genus; teeth small, canines much reduced, with triangular base, and in form resembling a premolar; forelimbs slender, with two functional toes, and a third one situated very much higher up, which is very rudimentary, and often overlooked; young animals have this third toe well developed; ears and tail long, like those of the Peragalea; tail compressed, and with a crest of hair running from the base along the upper ridge, and ending in a tuft.

\section{Pig-Footed Bandicoot (Choropuls castanotis).}

Fur long, loose, and rabbit-grey, beneath whitish; ears long, covered with small rusty hairs; tail covered with short hair, and with longer on the upper edge; eyes very large. The first specimen of this curious aninal was discovered by the late Sir T. A. Mitchell, Surveyor General, near the junction of the Murrumbidgee River, on the 16th June, 1836 . This first specimen had accidentally lost its tail, and from this Sir Thomas concluded that it was a peculiar characteristic; but all subsequent examples had the caudal appendage, which, in shape and the distribution of hair resembles the tail of Peragalea lagotis. The fur in both species is rery soft, whilst all the true Bandicoots have very harsh fur.

\section{Genus Perduetes.}

Feet, tail, and ears rather short; the hind foot with a rudimentary inner toe or thumb. Fur composed of hairs of two kinds; the one forming a soft under-fur, the other lairs coarse, flattened, and longitudinally groored; tail short, clothed with small adpressed hairs only. Five species are on record, of which three are found in New South $W$ ales.

Short-eared Peranels or Bandicoot (Perameles olesula).

Head moderately long; fur rery harsh to the touch, yellowish-brown, mottled with black above, sandy below; feet pale-yellowish, short, and rather thick; the ears are very short, and the skull, as in all other Peramelidk', is thin and delicate; the teeth, even in young animals, appear always much worn, and the true form of the grinders can only be determined upon the examination of immature subjects. The dentition approaches to that of the Dasyurirke in the form and position of the molars, but their worn surfaces always enable the student to distinguish them from the sharp grinders of the "Native Cats."

The present species has a very wide distribution, and is found in almost every part of Australia, and in Tasmania. In the neighbourhool of Sydney, however, the animal has never been observed. The short-eared Bandicoot, when kept about a house, will soon destroy all the mice, though he does not eat many of them, and prefers roots, grubs, and insects, to a flesh diet. It has been noticed that when one of these animals was put into a large case with a number of mice, he would quickly destroy them in the following manner:-The victims were tumbled about with his fore-feet, and their limbs broken; when the whole were disabled the Banclicoot began to derour a portion of each-generally the brain only.

Long-Nosed BANdicoot (Perameles nasuta).

Muzzle very elongate; ears of moderate size; general colour greyish-brown, beneath white, or yellowish-white.

Habitat-New South Wales, more particularly the Coast district. The present species is excellent eating, and the largest of the tribe.

Gunn's Bandicootr (Pércimeles gumii).

Upper parts of body grey, pencilled with yellow and black; under parts white; hinder parts of back blackish, with lighter bands; feet and tail white. This appears to be the next largest species; it is closely allied to the other striped Bandicoots of the mainland, and inhabits Tasmania exclusively.

Striped Bandicoot (Perameles fasciata).

Fur rather long, and harsh to the touch; the hair composing it is grey at the root, pencilled with yellow, and tipped with black; upon the back it is darker than on the sides; three black stripes corer the loin. The present species, the smallest of the tribe, inhabits the interior of New South Wales, Northern Victoria, and South Australia. The West Australian Saddle-backed Bandicoot (Perameles myosurus) is probably a Jocal rariety, in which the markings are less distinct. The weight of the smallest species does not exceed a lbs. 



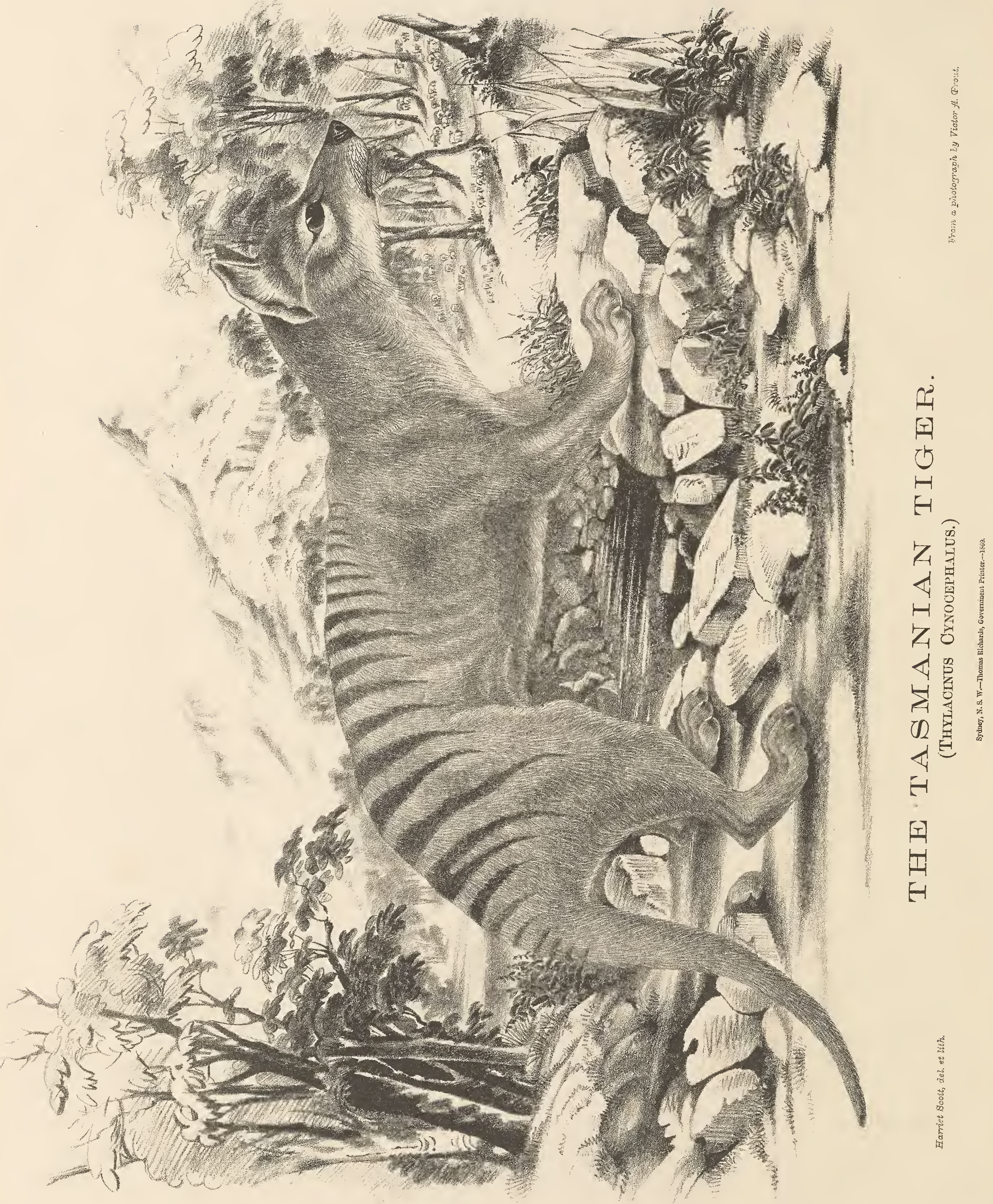




\title{
Dog-headed Thylacine, or Tasmanian Tiger.
}

\author{
(Thylacinuss cynocephalus.)
}

Tirs anımal is the largest and most ferocious of the whole Mammalian Fauna in Australia, and at the present time restricted to the island of Tasmania. It inhabits the wild rocky mountain districts, and frequently visits the plain country to attack the sheep-folls. The flock-owners try everything in their power to exterminate this dangerous creature, and it has consequently become very rare in the more populous districts. The summits of the western mountains of Tasmania appear to be their stronghold. These inhospitable regions are about 3,500 feet high, and the climate is consequently very cold in winter-time. We have been informed that when the snow is on the ground the "Tiger" or "Hyana" (as the Tasmanians call this animal) is easily trapped; a very powerful instrument is however necessary to retain them, and if they can reach the captured limb they are certain to gnaw it off. Mr. Masters, a careful observer, states that he has noticed the tracks of the Tiger after a fresh fall of snow, followed first by the not less ferocious Black Dasyure, by ordinary "Native Cats," and even by the smaller species such as Antechinus swainsonii, all going one after the other in expectation of joining the feast in their turn. Some of the shepherds state that one of these animals will kill hundreds of sheep in a very short time, and instances are on record of men having been attacked by them.

The number of young brought forth at a time does not exceed four; they are carried in a pouch, and when born are as small as young Kangaroos, but the well known marsupial bones with which all the other pouched animals are furnished are not found in the Thylacine. The animal is peculiar to Tasmania; but, as fossil remains prove, has once also existed on the mainland. There are two varieties which the shepherds have distinguished for years-one called the Bull-head the other the Grey-hound Tiger. The difference between them is a shorter head and closer packed and larger teeth in the first-mentioned species.

As it is not possible in the present work to illustrate all the members of the family to which the Thylacine belongs, we shall give a brief list of all the genera and species hitherto described, which will greatly assist the student in his labours.

\section{DASYURUS FAMILY - (FAMILY DASYURIDAE.)}

Marsupialia having the second and third toes of the hind feet disunited and well dereloped: the thumb or first toe small or absent; the tail non-prehensile and hairy; the canine teeth well developed, except in the small species of the genus Antechimus, and the molar teerh either with trenchant crowns or with the masticating surface presenting numerous prickly points.

The family is subdivided into the following groups or genera:-

\section{GENUS MYRMECOBIUS.}

General habit and size like a squirrel; head flat and broad, muzzle slightly elongated, muttle, nose, and ears of moderate size and pointed, tongue long and slender, legs short and strong, toes, five in front and four to the hind feet, all bearing compressed curred nails, tail long and bushy; female provided with four manme but destitute of a pouch; teeth small and detached, incisors $\frac{4-4}{3-j}$, canines $\frac{x-1}{t-1}$, molars $\frac{8-8}{9-9},=52$ teeth.

\section{Banded Mrrmecobius (Myrmecobius fitsciatus).}

Fur harsh and adpressed, rusty red of various shades, more or less pencilled with white in front, but much darker on the hind part of the body; beneath dirty white; from seven to eleven white bands across the back, the interspace between them increasing as they approach the tail. A black mark or band runs from near the muzzle to the ear, enclosing the eye. The ears are small, narrow, and pointed; the tail is bushy; and has a flat appearance. There are many points in the anatomy of this singular animal wherein it resembles the Ant-eater (Eschidnu hystrix); these are-the long and narrow palate, the roundeci brain-case, the strong limbs, elongate tongue, and weak mandible. The teeth are small, weak, anıl do not touch each other; in their number they are not exceeded by any living Mammal, and approach those of the extinct Phascolotherium,---one of the oldest of the Mammalian Fauna known to us. The two first lower incisors are curved. and directed upwards, resembling the same teeth of some Phalangers. If there is a tendency on one hand to approach the form of the Ant-eaters. there is on the other some relationship with the Phalangers, and $\left(3 x \cdot 16^{\circ}-\pi\right)$ 
more so with the little Tarsipes: both animals have delicate heads witl weak jaws, and the teeth standing far apart; both possess a long slender tongue, a harsh fur, and four mammæ, like all true Phalangers. We have not been able to ascertain whether any marsupial bones are present; if so they are very small, as in a specimen under examination they could not be felt.

The statement made by some authors that the number of mammæ is eight, and that from five to nine roung are produced in a litter, is erroneous. We have had an opportunity to examine several female specimens, every one of which had only four teats, generally all drawn, and proving the production of four young only.

The Myrmecobius is common on the West Coast and in the interior of New South Wales and South Australia: the Murrumbidgee River may be taken as its most eastern boundary. The food of this animal is said to consist of ants and their eggs; but it is probably augmented by honey and other vegetable substances, for the extraction of which from flowers or the hives of the wild bee it is well adapted.

\section{GENUS PHASCOGALE.}

Dasyurida, with the two foremost incisors of the upper and lower jaw larger than the others; premolars $\frac{3-3}{3-3^{3}}$, true molars $\frac{4-4}{4-4}$, studded with prickly tubercles; those of the upper jaw with triangular crowns; the last tooth very narrow and transverse. Five toes to each foot, the inner toe of the hind foot a nailless thumb. Tail iong and bushy: mammæe eight, pouch absent.

\section{Brush-taimen Pifascogale (Phascogale penicillata).}

Fur rather long and soft, grey, pencilled with white, beneath white; tail long, black, and bushy towards the tip, basal portion covered with short grey hairs.

Habitat-Australia generally, with the exception of the most southern parts of Tasmania.

This species was already known to the first settlers, and figured as far back as I798, by White, in his Journal. uncler the name of Tapera tafa. It appears however, that this nane is frequently applied to other animals, such as "Native Cats" or Phalangers. The Brush-tailed Phascogale is about the size of a Rat, arboreal and nocturnal in its habits, and a harmless creature, though authors (but not observers) differ on this point, and put the animal down as most ferocious and a terror to the hen-roost. It is expert in killing mice, but would certainly not attack a fowl. Like all other members of this group, it is in the habit of folding clown the ears, which are very seldom carrierl erect.

\section{Haxisone-talemd Phascogale (Phascogale calura).}

General colour ashy grey with a wash of brown, beneath whitish; tail corered at the base with short rustcoloured hairs, tip forming a brush of black hairs.

The habitat is given by authors as Western Australia; it occurs however also in New South Wales, near the Darling Kirer.

\section{GENUS ANTECHINUS.}

General character of Genus Phascogale:-Tail short, without a brush at the tip; canines not very prominent, with a broad base; female with a shallow pouch containing from six to ten teats, and with as many young in a litter.

The greater number of species composing this group of insectirorous marsupials are small, and closely allied to each other, so that the classification based upon the colour and length of the fur cannot be depended on.

Our most prolific author enumerates fourteen species without describing the dentition of one, and after a careful examination of animals, the hair of which answered to his description, we have arrived at the conclusion that the following number can only be retainer as specific examples:-

Tasmanian Antechinus (Antechimus swainsonii).

The largest of the genus, general colour dusky-brown or almost black. Specimens occur however which are more of a rust colour. Beneath more or less greyish white. Total length eleven inches.

Habitat-Tasmania. 
FreckLed Axtechines (Antechinus apicalis).

General colour grey-brown, of a very rich brown hue on the hinder parts of the body; on the head and fore-parts of the bedy distinctly freckled with black and white; under-parts dirty yellow-white; fore-legs of a bright rust colour; hind-legs distinctly tinted externally with the same colour; tail clothed at the roots with hairs like those of the body; but with the hairs becoming gradually shorter towards the apex, where they are black. Total length, 9 to Io inches.

Habitat-West Australia. Called "Dibbler" by the Aborigines of West Australia.

YelLow-Footed Antechinus (Antechinus faripes).

General colour of upper parts grey, towards behind rusty-tinted; feet and under-parts of body of the same rust colour; tail much darker. Total length, $8 \frac{1}{2}$ inches.

Habitat-Australia generally.

Stuart's Antechinus (Antechinus stuartii).

Rather larger than the previous species, and of a more uniform colour; grey, with a wash of brown, probably a variety of $A$. flavipes.

Spotted Antechinus (Antechimus maculatus).

This is a small species from New South Wales (Clarence River district); colouration dark blackish-brown above and slate-grey below, with a few white spots, and a similar spot on the throat. The following small species is probably a variety of it.

Litrte Antechunus (Antechimus minutissimus).

This is probably the smallest of the group; above greyish-brown, lighter beneath. Total length, perhaps 3 inches. We noticed a specimen in the Musuem collection, obtained by Mr. G. Masters, which had six good-sized young attached to the nipples. The mother was trailing them along the ground with some difficulty, when he bagged the whole family group. Though we have often stated a certain number of mammæ to be constant in certain species, this cannot be relied upon always. This specimen has six young, six drawn nipples, and an odd one on one side, distinct but not in milk.

The animals which we have had under consideration belong to what we have described in a former paper as the broad-footed section, and they number five in all; they are more or less arboreal in their habits, and their fur is only moderately soft.

We will now enumerate the members of the remaining section, which have been classed under the generic name of Podalrus.

\section{GENUS PODABRUS.}

Comprising the silky-furred and slender-footed species, with more or less terrestrial habits.

The following animals possess a skin as delicate and soft as a mole, but of longer texture; the tail, often incrassated, is covered with short adpressed hair, unlike the Antechini proper, in which the hairs of the tail are always of unequal length, and very harsh to the touch.

\section{White-footed Antechinus (Podabrus allipes).}

Three species appear to be enumerated of the white-footed silky-furred section; but the other two are no doubt identical with the above, though named otherwise and respectively Antechimus leucopus and fuliginosus. If, after careful investigation of their anatomy, we should come to the conclusion that they constituted three distinct species, the result will be made known, though it will not alter much our present arrangement. These little animals are by no means rare in less settled parts, and are caught in large numbers by the aborigines of the Murray and of King George's Sound. In the immediate neighbourhood of Sydney they have been found occasionally under stones during the winter-time, but never more than about two in three years by one collector. Their nocturnal habits and small size make it difficult for the best observer to obtain specimens.

The two remaining species, which are distinguished by a tail more or less incrassated, but appear otherwise identical with P. albipes, are named Thick-tailed Podabrus (Podabrus crassicaudatus), and Large-tailed Podabrus (Podabrus 
macrourtes): the first discovered by Mr. Gilbert, in West Australia; the last from the Darling Downs district, obtaned by the same indefatigable naturalist, to whom Mr. Gould is indebted for his choicest specimens. It is necessary to state that the figures which we see of these animals are not quite correct, the tail being always exaggerated.

\section{Mitchell's Ponabrus (P'odabrus mitchellii).}

This species is by far the largest of the small Dasynuida with thick woolly fur. A single mutilated specimen, with a note attached intimating that it was obtained by Sir Thomas Mitchell, was found in the Museum some years ago, and may be described as follows:- Fur thick and silky, resembling the fur of phascogale lanigera of Gould; general colour, slate grey with a wash of brown, beneath white; ears rather long; feet white; total length eleven inches: the tail being about five and a half inches, and probably furnished with a tuft of hair. The large tarsi and long tibia indicate that the animal moved by a succession of jumps; the specimen is, however, too much mutilated to enable us to judge about this characteristic with certainty.

Habitat-The interior of New South Wales.

\section{GENUS ANTECHINOMYS}

Terrestrial Dusyuride, with long Kangaroo-like hincl-legs, and four toes, the thumb being absent; tarsi covered with hair, the toes only being naked. Dentition like Podalrus, with canines still less developed.

The genus comprises only one species,- the animal described by Mr. Gould as Phascogale lanigera.

Wooliy ANTEchinomys (Antechinomys lanigera).

Fur long and silky, general colour greyish-brown, beneath white; tail as long as the body, with a tuft of moderately long fine hairs; progressing by a succession of jumps. The female has no pouch, and is provided with eight mammæ.

Habitat-The incerior of New Sonth Wales and Victoria.

\section{GENUS CHATOCERCUS}

Head shor, broad behind, almost triangular; auditory bulla very large; upper canines strong and elongatc, not so broad at their base as in the genus Phascogale; incisors long and narrow, resembling those of Dasyumus, first pair directed forward, and slightly larger than the others; pre-molars, three in the upper jaw, the middle one largest, the first somewhat smaller, and the third and last very diminutive and tubercular; molars of the usual triangular form, with rather blunt tubercles, increasing in size from the first to the third, the fourth being narrow, transverse, and resembling the same tooth in the genus Dasyurus. The lower jaw is short and strong, and the articulating condyle is placed still higher comparatively thin in any other species of this group; the incisors are three in number, the first pair being the largest; canines smaller than those of the upper jaw, sharp and pointed, and devoid of the broad base common to other small Dasyures. Of pre-molars the lower jaw contains only two, the first larger than the seconcl. There are four molars, the first and last being the smallest, the two niddle ones of about equal size; on the first the anterior tubercle is scarcely indicated, showing, with the absent third pre-molar, a close approach to the genus Dasyurus. Tail thick, with compressed sides, ornamented by a crest of hajr on the apical half, similar to the tail of the Pig-footed Bandicoot (Choropus castanotis).

\section{Cin ESTED Catocercus (Chetocercus cristicanda).}

General structure similar to that of Phascogale calura; limbs strong, furnished with long claws; five toes to the fore and hind feet, the inner toe of the latter a short nailless thumb, the hair covering the fore-feet long and shaggy; colouration rusty-brown, the fur being of a dark leaden-grey at the base. Total length 8 inches, tail $3 \frac{1}{4}$, head to base of ear $I$, tarsi and toes $I \frac{1}{8}$ inches.

Habitat-South Australia, probably the neighbourhood of Lake Alexandrina. 
GENUS DASYURUS.

Flesh-eating animals, of moderate size, with spotted or striped fur; they resemble the Martins and Polecats of the placental order Carnivora, and are best known to the Colonists as Native Cats, or Tiger Cats, 一the larger Tasmanian species as "Devils," Tigers, and Hyænas; they have, however, no relation to the Cat tribe, and are Marsupial animals, with a shallow pouch or skin-fold. The teeth of the Dasyuri resemble those of the smaller Phascogales and Antechini, but the pre-molars reduced by one in each ramus. The Thylacinus is, however, an exception, and has three pre-molars in each ramus. The dental formula stands therefore (Thylacinus excepted):- - Incisors $\frac{4-4}{3-3^{3}}$, canines $\frac{x-1}{x-x^{3}}$ pre-molars $\frac{2-2}{2 m-2}$, molars $\frac{4-4}{4-4}=$ 42 teeth.

Viverrine Dasyurus (Dacyurus viverrimus).

Fur rather long and soft; tail bushy; ears long, generally carried folded down. General colour black spotted with white, or yellowish spotted with white; under parts of body lighter. No inner toe or thumb to the hind-foot. Female with six mammx, and generally four young at a litter. Total length 23 to 24 inches, of which the tail measures 8 or $8 \frac{1}{2}$ inches.

Habitat-Southern Australia and Tasmania. We do not think that this Dasyure inhabits the West Coast.

North Australian Dasyure (Dasyurus hallucatus).

Fur of moderate length, and rather harsh; general colour of the upper parts of the body dusky brown, much pencilled with yellowish, and having numerous irregular white spots; under-parts white suffused with yellow; tail bur little bushy, cylindrical, the apical half or more, black.

The above is Mr. Waterhouse's description of a British Museum specimen, who also states that the animal is less in size than either the Common or Geoffroy's Dasyure. The hind-foot is provided with a thumb. Nothing is stated about skull or skeleton, and though we enumerate the species as distinct for the present, it will be seen when the description of Dasyurus geoffroyi is compared with it that both animals are identical. The habitat is given as North Australia, Port Essington.

Geofrroy's Dasyurus (Dasyurus geoffroyi).

Fur moderate, general colour of the upper parts yellowish pencilled with black, and having numerous irregular white spots; body beneath white; tail imnaculate, black at the apex; hind-foot with a thumb.

Habitat-West Australia, South Australia, and New South Wales.

The fine series of Dasyures in the Australian Museum enables us to state without doubt that both species, Dasyurus hallucatus and Dasyurus geoffroyi, are varieties of each other. The Museum is in possession of specimens which answer to both descriptions-specimens in which the yellow and some in which the darker tint predominates. There is one example with a very bushy tail and scarcely any black hair at the apex, and there are others with a cylindrical tail, which is tipped with black. Colouration is of very little value in the determination of species, and as we have compared the skulls of these various coloured animals, we can only state that they differ in hothing material except size. The largest specimens occur on the Murray River, those from other parts of South Australia are much smaller and darker in colour, but now and then. examples are found which are pale yellowish.

The name of Dasyurus geoffroyi should therefore be aclopted for both animals. On the east coast this Dasyure has not yet been noticed.

\section{SpotTED-TAlled Dasyurus (Dasyurus maculatus).}

Fur rather harsh and short; general colour from deep brown to light reddish brown pencilled with yellowish; body beneath sandy-coloured, the whole, including the tail, spotted with white; a thumb to the hind-foot.

The present animal differs as much in size and colour as did the last-mentioned species, and its geographical distribution is as extensive. Tasmania, Victoria, New South Wales, and South Australia, have accorded it as inhabiting these Colonies. We have also seen examples from Queensland. It is peculiar to the Coast Districts, but has not yet been observed in the far North or on the West Coast. The spotted-tailed Dasyure grows to a large size, and is provided with most formidable teeth. Mr. Waterhouse, the able naturalist, who has written a most raluable work on the Marsupialia, mentions a skull as that of an aged individual 3 inches $6 \frac{1}{2}$ lines long; but a specimen in the Australian Museum measures fully $4 \frac{1}{2}$.inches, and the upper canines are $1 \frac{1}{4}$ inches in length. Specimens have been observed as large as a common Fox; and as these animals are not only very ferocious but also exceedingly stubborn, it frequently happens that they make great havoc if they gain admission to the poultry-yard of the settler. 


\section{GENUS SARCOPHILLS.}

Dasyuri with a short and stout body, short and broad head, and powerful compact teeth, which are packed so close together that there is not a line of space between them; legs rather long, tail short and thick.

Ursine Sarcophulus or Tasmanian Bhack Dasyure (Sarcophilus ursinus).

Fur coarse, of moderate length, and black, here and there with a white spot or two; these spots occur most frequently on the breast or loins.

Mr. Waterhouse gives the measurement of a skull as 4 inches 6 lines, another in the Australian Museum collection measures 6 inches, and is $4 \frac{3}{4}$ inches wide. The ferocity of these animals is almost beyond belief; they attack every living thing, and are most destructive to sheep, though not larger than a common Terrier Dog.

One of them, and by no means a large one, escaped not long ago, and killed in two nights fifty-four fowls, six geese, an albatross, ${ }^{*}$ and a cat. Having been recaptured in what was considered a stout trap, with a door constructed of iron bars as thick as a lead-pencil, he made his escape by twisting this solid obstacle aside, almost doubling it up with his powerful teeth. To give some idea of the strength of the animal, we mention that the blacksmith who repaired the trap could not bend the bars back into their position without proper tools. When caught in a fox-trap the black Dasyure often bites off the fastened limb and escapes. A specimen in the Museum Collection, the largest ever secured, had only three legs; one of the hind limbs was clean gone, and not even the trace of a stump remained visible. The fossil Sarcophilus laniarins of the Wellington Cares was a still more powerful animal. Numerous bones and teeth prove the existence of large numbers of these creatures during post-pleiocene times, which must have made havoc among the more peaceful animal tribes. There can be no doubt that they were a terror even to some of the gigantic creatures, whose young they probably devoured whenever any opportunity offered.

We have noticed before the total absence of large fossil Carnivores, which were supposed to be necessary to check the undue increase of the herbivorous marsupials; but with such strong and blood-thirsty creatures as this small Dasyure, no great Carnivores were required to carry out the designs of the Creator.

The habitat of this animal is restricted to the island of Tasmania.

\section{GENUS THYLACINUS.}

Dasyurida, with the outermost incisors exceeding the others in size; the three foremost of the upper true molars with a much-elevated central cusp, an anterior and posterior cusp but little elevated, and an internal lobe; the hindermost of the upper true molars transverse; the true molars of the lower jaw nearly resembling those of the upper jaw, but destitute of internal lobe, and with the central cusp more elevated; the humerus with the inner condyle perforated; the hind-foot destitute of an inner toe; a well-developed pouch with four mammx, but without marsupial bones. The pre-molars resemble those of the genus Phascogale, and are three in number in each ramus.

\section{Dog-headed Thylacine, or Tasmanian Tiger (Thylacimus cynocephalus).}

About equal in size to the common Wolf; tail about half the length of the body; fur short, and closely: applied to the skin; general colour grey-brown; the back with about twelve to fourteen transverse black bands, narrow and short on the fore-parts of the back, longer and broader on the hinder-parts; region of the eye pale; tail with short fur, nearly like that of the body, excepting on the under-side of the apical portion and at the tip, where the hairs are comparatively long. The Thylacine stands lower on the legs than either Wolf or Dog, and in every respect resembles the smaller Dasyures; like the Sarcophilus it is a most ferocious and formidable animal, which will soon overpower even a Cow or Morse if driven by hunger to attack them; it is also stated that the creature is not afraid of man, and will show a formidable front when driven to extremities.

We know one large fossil species, which was the largest Marsupial Carnivore on record, and inhabited the mainland of Australia in former ages; at the present time the Thylacine is restricted to Tasmania.

\section{Shorr-iEaded Thy Lacine (Thylacinus brevicep.s).}

This species has been founded on two skulls obtained by Mr. Masters on the Ouse River in Tasmania. The skulls are those of young animals, and show the distinguishing characteristics well. The head is shorter, the pre-molars 
much closer together, and, like all the other teeth, larger than in the common Thylacine; this is best seen when we compare a full-grown Thylacinus cynocephalus skull, with one of the Thylacinus treviceps, which, as regards size and position of the teeth, gives the following result :-

A large skull of the common Thylacine measures, from the occipital foramen (the opening at the back of the head) to the incisor teeth, exactly 9 inches. The width of the palate in front of the last premolar measures slightly more than I inch. The palatial opening is $1 \frac{1}{4}$ inches in length, and a little more than $\frac{1}{8}$ th of an inch wide, and the median line of the palate is imperfectly anchylosed. The last molar but one-the largest of the series-is $\frac{3}{4}$ of an inch wide in its broadest part, and the space between the two first pre-molars measures $\frac{7}{2}$ an inch in width.

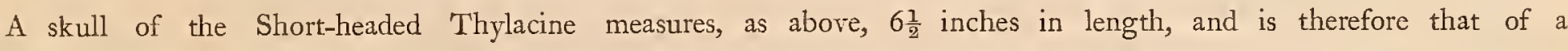
much younger animal, and yet the palatial opening is reduced in size, forms two small holes less than I inch in length, and $\frac{1}{4}$ of an inch wide, and the median suture is completely closed up. The width of the palate in front of the third pre-molars is as large as in the adult $T$. cynocephalus, and the largest molar exceeds in size by $\frac{3}{8}$ th of an inch that of the greater specimen. The space between the pre-molar teeth is less than $\frac{1}{8}$ th of an inch, but in the larger one it is double that width,-which shows that the teeth of $T$. breviceps are much closer packed. Comparing the skull of a younger $T$. cynocephalus with that of $T$. breviceps, all the differences in the size of the teeth become more striking, and other diverging points could be mentioned were further proofs required of the correctness of these observations. Professor Owen at once acknowledged the truth of this statement, and accepted the $T$. breviceps as a distinct species, but our Tasmanian friends continue to consider the two animals as varieties only.

The foregoing discussion will prove the value of Comparative Anatomy when determining species, and also the advantage of having many specimens for examination. Kind donors to the Museum must not apprehend that their most liberal presents will ever overstock the collection, because the larger the number of skulls or skeletons the better will the animals of this Country be understood by future generations. It is exactly with Comparative Anatomy as with the science of Meteorology: had the changes in the atmosphere been as carefully noted a hundred years ago as at the present time, great results could be deduced therefrom. Let us therefore advise our friends to gather their specimens in time, or it may come to pass when the last Thylacine dies, that the scientific men across Bass's Straits will contest as fiercely for its body as they did for that of the last aboriginal man not long ago. A similar want of forethought occurred in New Zealand, where a great trade with smoked human heads at one time existed. The British Government soon stopped the abominable traffic, and Dr. J. Haast, F.R.S., the well known Geologist, and Director of the Christ Church Museum, is, now offering fabulous exchanges (a complete Moa we believe), for such a trophy whereof not one is to be found in New Zealand-the Australian Museum possessing two of them. The products of a new country should be secured as early as possible, and every object bearing upon the manners and habits, the arts and manufactures of a primitive race, should be gathered and deposited in some public Institution before it is too late. Animals and plants are often very local in their habitat, and soon disappear before the steps of civilization; as an example, we may mention the beautiful Nestor-Parrot of Phillip Island, which has long ceased to exist there. The island is a dependency of this Colony, but only one very bad specimen of this rare bird remains now in our collection. 



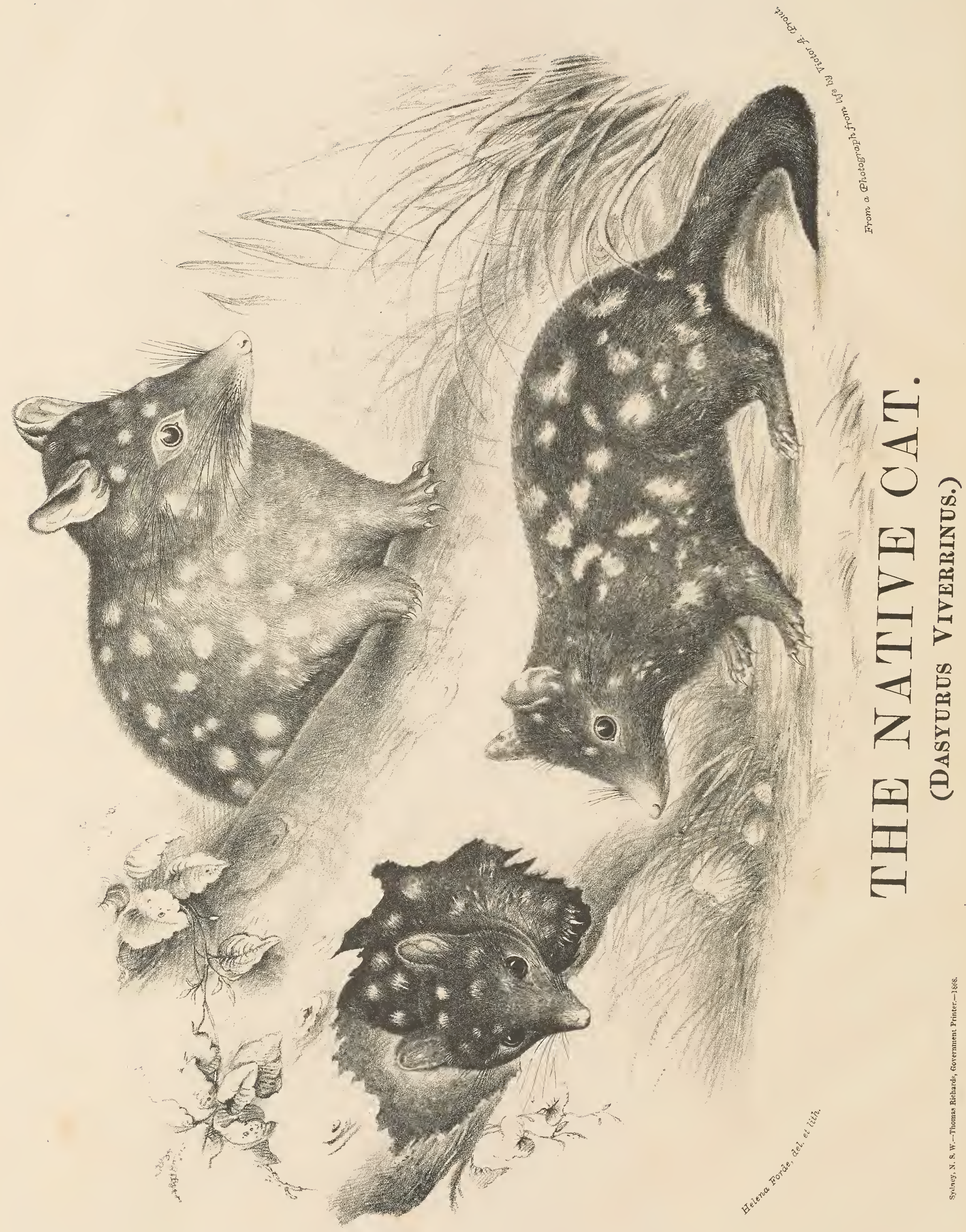




\title{
The Native Cat.
}

\author{
(Dasyurus viverrimus.)
}

HArus already given a full account of the family of Dasynicke elsewhere, there remains nothing but to add a short notice of the most common and hest known of the tribe, - the black and white, or buff and white-spotted "Native Cat" proper.

These little creatures, with their fierce disposition, are familiar to the greater number of Colonists; they inhabit our forests, but prefer to take up their abode with civilized man when they find out that he keeps plenty of meat about his habitation, or rears poultry. They are rery savage for their size, and fire of them kept in a cage without sustenance for a day only, had almost reduced themselves to the state of the famous tabbies of Kilkenny. The fact 1.5, they devoured each other till only a pair remained, and the savage look and watchfulness of these two animals was amazing to behold.

They are stubborn in the extreme, and appear to care about nothing. We have noticed them to come quite unconcemed into a tent at night, and take up a cosy place near the chimney; from which a firestick only could dislodge them. Another case was mentioned not many days ago, when one of the Tiger Cats actually faced a halfcaste man, who was terror-stricken, and ran away. A real aboriginal native, one of the old tribes, would have made short work of such an adversary; but these poor people have now almost died out, and the few still lingering behind cannot eren remember the animals which their ancestors hunted.

The common Native Cat of this Colony is about the size of a half-grown domestic Cat; but further south, and more particularly in Tasmania, it grows somewhat larger. The colour is black with white spots, or yellowish-grey with white spots; the tail rather bushy, and uniform in colour, whilst that of the larger Tiger Cat is smooth and spotted with white. The pouch, or rather skin-fold, with which the female is provided contains six teats, but the number of young setdom exceeds four. At a certain age the young are left in the spout-hole or crevice which the mother has selected for then whilst she goes out bunting, and on more than one occasion have we obtained young specimens (the size of a half-grown rat) from such lairs during the parent's absence. They begin to hunt at a rery early age; probably they are forgotten by the old ones as soon as they are able to more about and catch something on their uwn account.

The common Native Cat is destitute of the external fifth tne or thumb on the hind-foot: the bones can be distinguished, howerer, in the skeleton. With regard to their geographical range, we may safely assert that they are peculiar to the South and South-sast Coast and to Tasmania. The interior of the Colony is occupied by another species-Dasyurus geoffroyii-which appears to be identical with the northern Native Cat (Dasylurus halluratus). Not a single species has been recorted as inhabiting the West Coast.

$15 \times 18 \%$ 




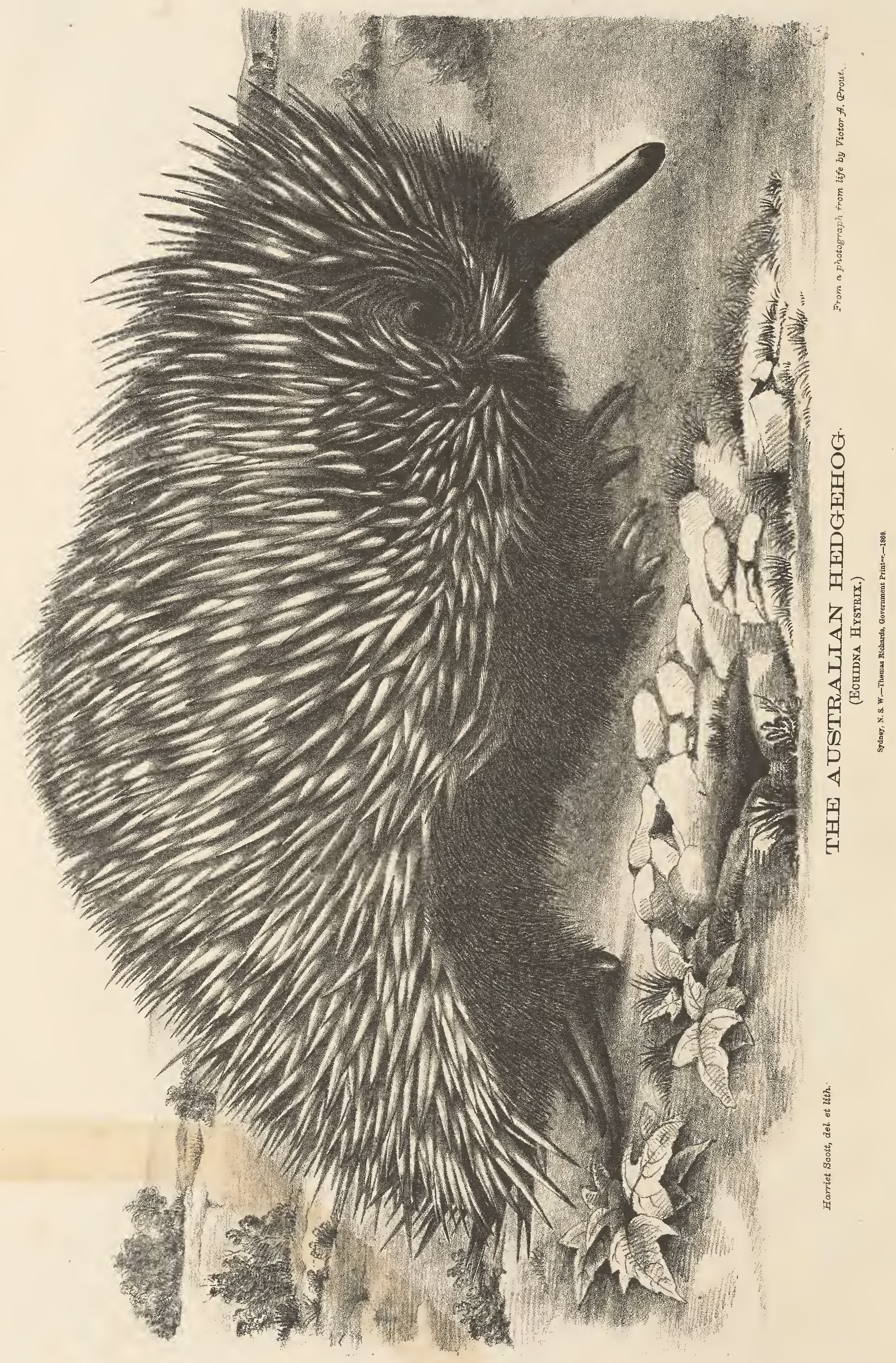




\title{
Spiny Ant-eater.
}

\author{
(ECHIDNA HYSTRIX.)
}

A sub-section of the family Marsupialia comprises the Monotremata, with only two known species, one of which, the Spiny Ant-eater, we figure. It is, like the Platypus, a strictly Australian animal, and inhabits almost every part of the Continent, from Cape Howe to Cape York, but is not found on the salt-bush plains of the interior. The Tasmanian species is more hairy, and has been noticed under another name (E. setosa), but both animals are only varieties. Dr. Shaw described the Echidna and the Platypus about the close of last century, and great interest was shown by anatomists and physiologists in these discoveries, which raised the unsolved question, —whether the two creatures laid eggs! The greatest men of science gave their opinion for and against this theory; and when Meckel (a well-known German anatomist) had actually discovered the mammary glands, proving thereby that the Echidna gave suck, Geoffroy St.-Hilaire (a great French savant) would not believe a word of it. Both naturalists have passed away, and it was left to Professor Owen to enlighten us on the manner in which the Spiny Ant-eater treats her young progeny. The condition in which the young come to light, corered by a shell or naked, we do not know; but a specimen forwarded to the Professor by Dr. v. Müller, of Melbourne (a full-grown female), contained two small apertures or pouches on the under side of the body, and these were occupied by two "little ones," then not much larger than a French bean. The milk-glands drained into these pouches, and supplied the necessary nourishment, but a teat could not be observed.

Professsor Owen has written a most elaborate treatise on the subject, to which we must refer our readers.* The discovery took place a few years ago, so that at least forty years passed before the dispute was settled.

Even now we are as ignorant as possible about the habits and economy of this well-known animal, and we certainly cannot tell what becomes of our spiny friends in summer-time. A keen observer, Mr. Charles Kepert, of Soldier's Point, Port Stephens, who always supplies us with Echidnas in winter, is of opinion that these animals retire into the ground,-in fact, hibernate during the hot season. So much is certain-they cannot be obtained so easily in summer.

The Echidna is about I 8 inches in length, of stout build; the upper parts covered with strong spines, underparts, head, and legs, clothed with brownish or blackish coarse hair; head with the facial portion prolonged into a slender and sloping snout, and covered with a naked skin; mouth-opening small; tongue long and flexible, with some horny, tooth-like ridges on the hinder part; legs short and strong, provided with five well-armed toes; tail short, covered with spines.

The food of the Echidna is said to consist of ants and other small insects, but we have on several occasions taken also grass from their stomachs. The jaw is toothless, but the ridges of horny tubercles before mentioned, and similar spines on the palate, probably assist in crushing the food.

The heel of the male is armed with a spur, which is movable, perforated, and supplied with a gland, and muscles capable of injecting the secretion of the gland through the canal of the spur, as in the Duck-mole. According to Messrs. Quoy and Gaimard the apparatus is not poisonous. We have often handled Echidnas, but never experienced any irritation when accidentally scratched by the spur.

The Echidna will live for months in captixity without- taking food; and Mr. Kepert's suggestion that the animal feeds in winter only, and hibernates during summer, is by no means improbable. It is difficult to drown one, and from eight to ten minutes at least are necessary for the experiment. The animal is also tolerably snake-proof, and a specimen frequently bitten by some of our most renomous reptiles lived for ten hours. The strength of the Echidnas is most wonderful, and their digging capabilities will scarcely be credited. The animal often appears to be nailed to the ground, and if sheltered in some convenient corner, where the soil is stiff clay, a spade is necessary to dislodge it. In soft alluvial soil or sand, an Echidna will disappear before the observer's eyes without any apparent effort, gradually sinking out of sight.

The best means to secure a runaway is to obtain hold of one of the hind legs, when the animal is unable to resist any longer. The flesh is considered excellent.

* On the Marsupial Ponches, Mammary Glands, and Mammary l'xetus of the Echidna Ilystrix. By Professor R. Owen, F.R.S. Philosophical Transactions, 1865 , p. 672.

$(3 \times 15-71)$ 



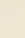




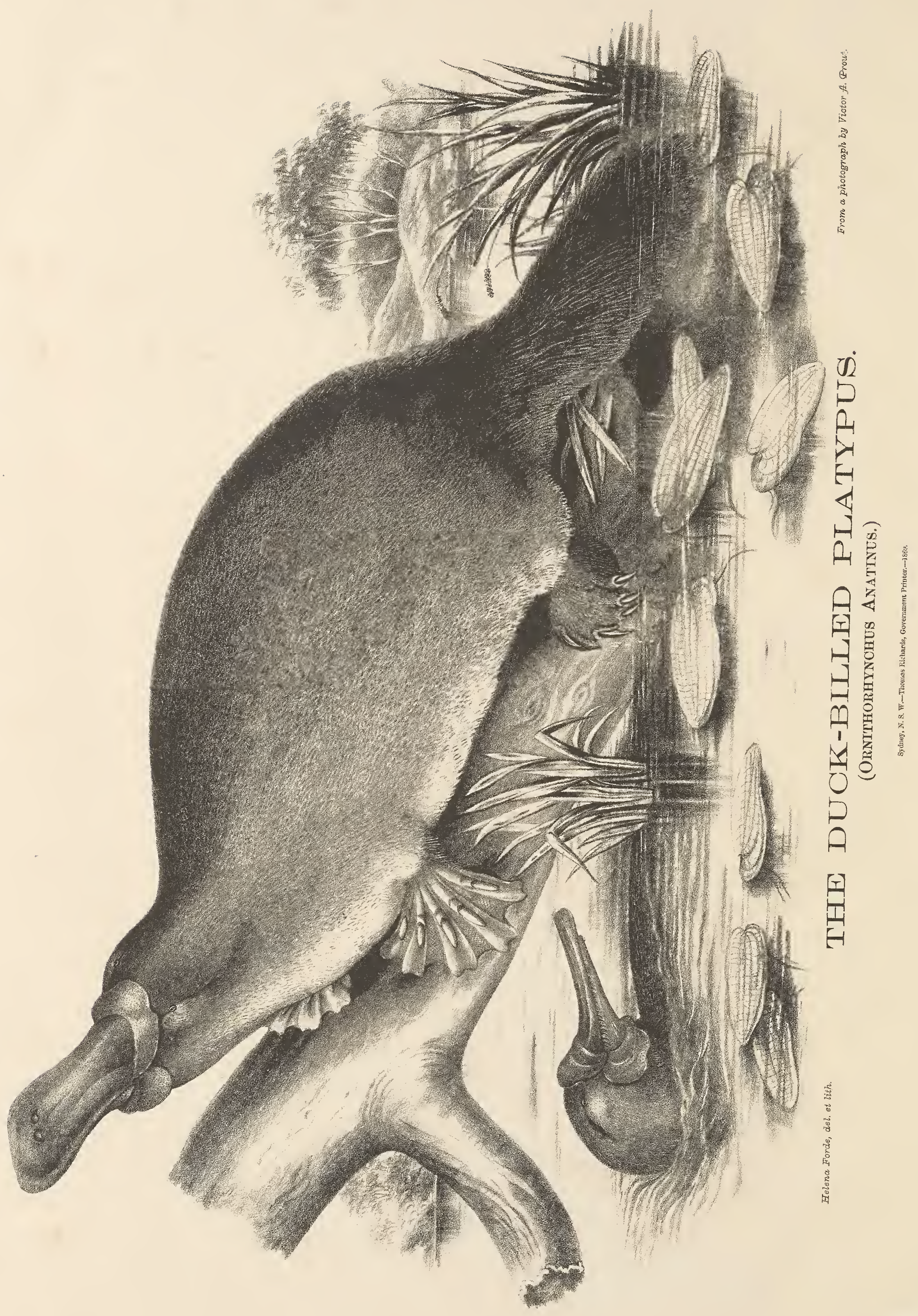




\title{
Duck-bill, or Water-mole.
}

\author{
(ORNITHORHYNCHUS ANATINUS.)
}

Our plate represents the most interesting of all the Australian animals, - the Duck-bill, Platypus, or Water-mole, which inhabits the quiet rivers, creeks, and lagoons of the greater portion of Tasmania and Australia. Known to everybody, and common in many parts, we have added nothing to the account given by Dr. George Bennett, F.L.S., \&c., more than thirty years ago. Professional naturalists cannot afford the time for investigation, and few settlers with plenty of leisure will understand the importance of some of the questions yet to be solved.

Dr. Bennett informs us that the Water-mole constructs a burrow under creek or river bank, with the entrance beneath the water; in this place the mother brings forth her young, some of which Dr. Bennett captured, and beyond this fact we know nothing whatever. Considerable rewards have been offered for young Water-moles from time to time, but none have come to hand, and all our appeals for specimens (shot during October and November) in the flesh have been made in vain.

The total length of a full-grown Platypus is about I 8 inches; the fur is short, dense, and velvety, that of the tail rather crisp; the general colour a dusky brown above, and somewhat paler below. Young and immature animals are bright brown above and whitish below. The few very young specimens obtained were from two to four inches in length, with very short beaks, and quite destitute of hair.

Unlike other mammals, the teeth of the Duck-bill are horny, and two are carried in each ramus above and below, giving a total of eight teeth; four of these, in the form of narrow strips, are situated in the fore part of the jaw, one in each ramus; the other grinder-like teeth are further back.

In harmony with its reptilian character,* we also find some horny teeth on the tongue, which is of moderate length. The eyes are very small, situated rather high up, at the base of the beak. The external orifice of the ear, hidden by the fur, is placed at a short distance behind the eye. The legs are strong, and very short; the feet provided with five toes. On the heel of the male is a large and sharply-pointed movable spur; this spur is pierced by a minute tube, the outlet of which is near the point; and, connected with this little tube, is a large gland, which is supposed to secrete a pcisonous fluid. Mr. G. R. Waterhouse, whom we have frequently quoted in the present work, and to whom Australia is indebted for the best Natural History of the Marsupials ever published, doubts the poisonous nature of the gland, and states that Dr. Bennett has made frequent experiments upon himself without any evil result. It is possible that the spur has some poisonous properties during certain seasons of the year, because we remember being cautioned to handle a male Water-mole, by a gentleman who said that he once had been wounded in the arm by one, and had suffered severely in consequence.

It is not our object to go into the anatomy of a species so well described by the able pen of Professor Owen. We refer our readers to the Professor's many papers on the subject, and sincerely hope that country residents will continue to collect Water-moles, and observe their habits, for the benefit of science. A solution of strong salt and alum is sufficient for the preservation of the bodies, which should be opened, well washed (but not otherwise meddled with), and then put into the brine.

September, October, and November, are the most favourable months for collecting, and females only, which are destitute of the spur, should be secured.

Water-insects, small mollusca, and the ova of frogs and fishes, constitute the principal food of these animals. 


\title{
ADVERTISEMENTS.
}

[The following Publications may be obtained at the Government Printing Office.]

Recently Published, by Authority,

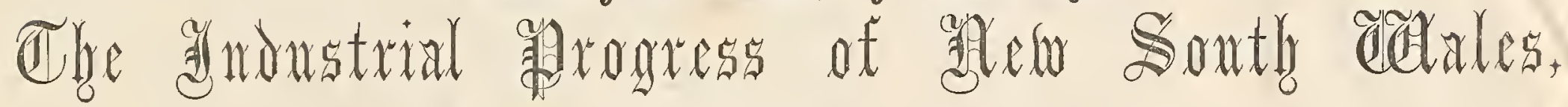

\author{
Gontaining a Goloured Map of the Golony,
}

showing the localitics of the various Mining, Agricultural, and Pastoral Industries; the Gold Fields, Vine-growing Districts, and Coal Deposits; the Railway and Elcctric-Telegraph Lines, and Coast Light-houscs.

This is the most complete Map yet issued by the Government. AISO,

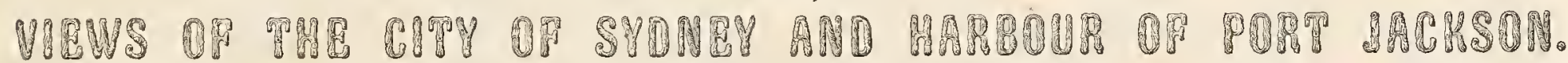

This Work embraces a general view of the progress of the Colony, during its first centenary period, in Arts, Manufactures, A gricultural, Pastoral, and Mineral pursuits; together with a Report of the Intercolonial Exhibition held at Sydney in the year 1870, and a Cataloorue of the Exhibits, and Judges' Awards, as well as separate and Original Papcrs on the Sedimentary Trormations of New South Wales, Mineralogy, Indigenous Woods, Orange Cultivation, Natural History, and other equally interesting subjects. The Book contains nearly 800 pages, Royal 8 vo. Price, in boards, 5s.; cloth, 10s.

Two Views of the Harbour of Port Jackson, on plate paper. One, taken from the North Shore, shows the whole of the Marbour, including the City of Sydney, from the Heads to the Lane Cove Rivcr, price 2s. ; the other, taken from "Ginahgulla," on the South Shore, shows accurately all the Bays and Points of importance from the City to the Heads, price ls.

\section{THE PUBLIC STATUTES OF NEW SOUTH WALES, \\ FROM 7 GEO. IV TO 25 VICTORIA.}

Tn 4. vols., cloth-bound. Price 23 ; originally $£ 5$ 5s. The subsequent Acts, from 26 to 34-5 Victoria inclusive, collected, quarter-bound, and lettered on edge to distinguish Sessional Parts. Price $226 \mathrm{~s}$.

The Private Acts of New South Wales, from 3 William IV to 26 Victoria, inclusive. Price 15s.; originally $£ 1$ ss.

The New South Wales Parliamentary Hand-book, compiled and edited by R. O'Connor, Esq., late Clerk of the Parliaments. Price 2s. $6 \mathrm{~d}$.

The Common Law Procedure Acts and Law of Evidence Amendment Act, indexed by H. Cary, Esq., M.A., late District Court Judge. Price $5 \mathrm{~s}$.

Crown Land Acts of 1861 and Regulations thereunder (Fifth Edition). Price 1s. 6d.

The Gold Fields Act of 1866 and Regulations of 24th September, 1869, to 25th August, 1871, inclusive. Price 1s.

Letters of Registration of Inventions under 16 Victoria, No. 24. Part I, £2 2s.; Part II, 10s.; Part III, £1 10s.

Report of the Commission appointed to inquire into the Supply of Water to Sydncy and Suburbs. Price £l.

Abstract of Meteorological Observations made in New South Wales, up to the end of 1869, with remarks on the Climate. s. d.

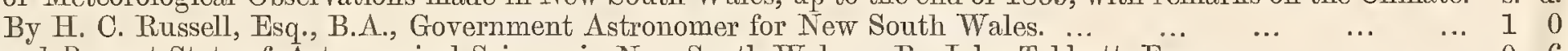

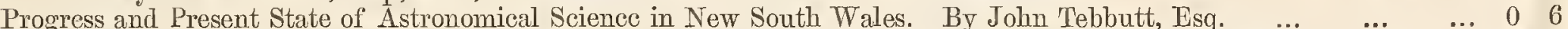

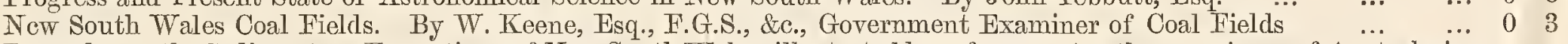

Remarks on the Sedimcntary Formations of New South Wales, illustrated by references to other provinces of Australasia.

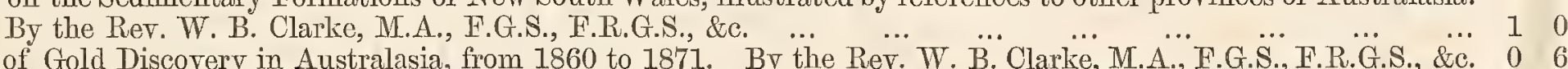

Progress of Gol the Diamond near Mudgee. By Norman Taylor, Esq., of the late Victorian Geological Survey,

$\begin{aligned} \text { and Professor A. M. Thomson } \ldots & \ldots\end{aligned} \ldots$

Introduction, Cultivation, and Economie Uses of the Orange and others of the Citron-tribe in New South Wales. By

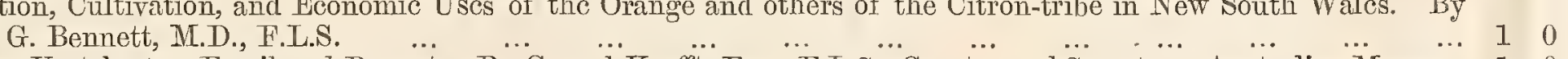
Australian Vertebrata—Fossil and Recent. By Gerard Krefit, Esq., F.L.S., Curator and $\ldots$ Secretary, Australian Museum 110

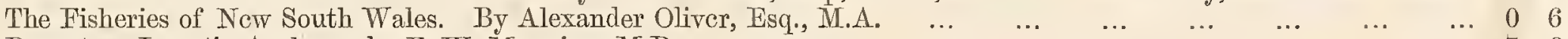

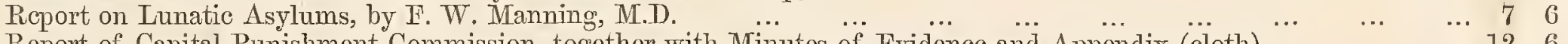

Report of Capital Punishment Commission, together with Minntes of Evidence and Appendix (cloth) $\quad \ldots \quad \ldots l l 26$ Report on the Common Schools System of the United States and Canada (cloth). By Rev. J. Fraser $\quad \ldots . . . . .786$

Reports of the Council of Education upon the condition of the Public Schools and of the Certificd Denominational

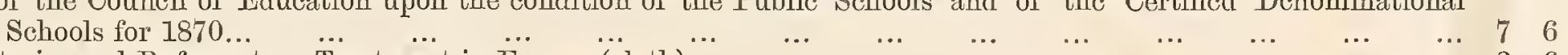

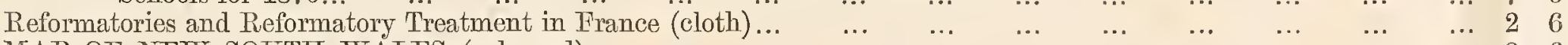
$\begin{array}{lllllllllllll}\text { MAP OF NEW SOUTH WALES (coloured) } & \ldots & \ldots & \ldots & \ldots & \ldots & \ldots & \ldots & \ldots & \ldots & \ldots & 2 & 6\end{array}$ Cereal Map of New South Wales (coloured) $\quad \ldots \quad \ldots \quad \ldots \quad \cdots \quad$ THOMAS RICHARDS, Government Printer.

\section{The Mlammals of Australia,}

Tlustrated by Miss Harriext ScotT and Mrs. Hedena Forde, for the Council of Education. With a short account of all the Species hitherto described, by Gerard KREFrt, F.L.S., Curator and Secretary of the Australian Museum. Price 12s. 6d.

\section{Kreffit's Snakes of Austrialia:}

A descriptive Catalogue of all the known species, with a full account of thcir habits and Geographical distribution; including hints with regard to the treatment of wounds inflicted by venomous Snakes. Illustrated by 12 Plates, on which all the known species are represented. Plain, 15s.; Coloured, 30s. To be had of all Bookscllers.

\section{Nearly Ready, \\ The Fossil Fauna of Australia,}

By Gerard Krefet, F.L.S., with 18 Plates of Tllustrations, by Miss HarriedT Scotw and Mrs. Helena Forde. 






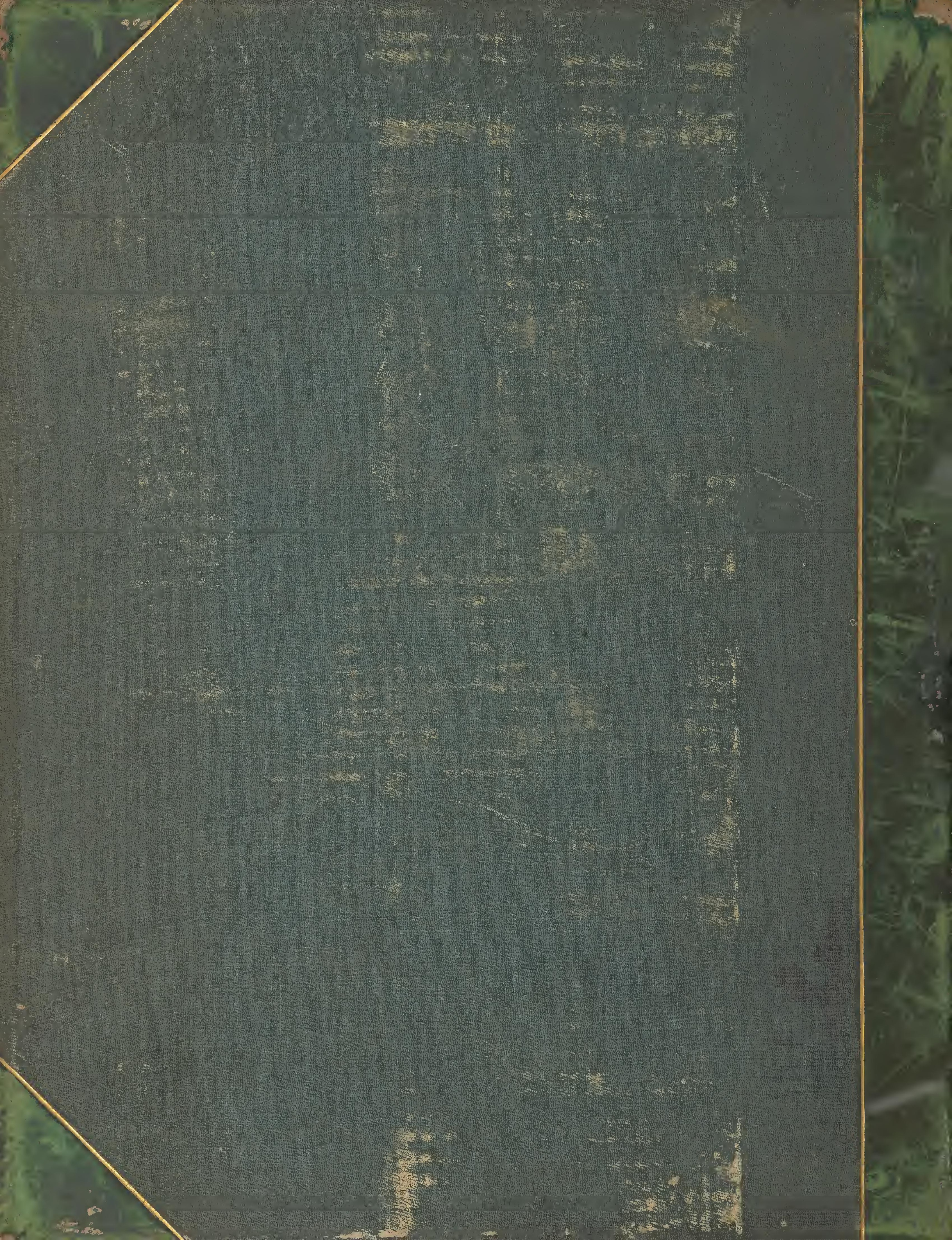

